\title{
ARCHEOLOGICKÝ VÝZKUM PLUŽIN A ZEMĚDĚLSKÝCH TERAS JAKO FENOMÉNU HISTORICKÉ KRAJINY ČESKÉ REPUBLIKY
}

\author{
IVANA ŠITNEROVÁ - JAROMÍR BENEŠ - BLANKA KOTTOVÁ - JIŘÍ BUMERL - \\ TEREZA MAJEROVIČOVÁ - KRISTINA JANEČKOVÁ
}

\begin{abstract}
Abstrakt: Plužina, historický pojem a v preneseném slova smyslu výrazný krajinný prvek nejen v České republice, ale i v celé středni Evropě, byla do nedávna z pohledu archeologie opomijenou součástí historické kulturní krajiny. Zájem archeologů se upinal předevšim na intravilán zaniklých vsí. Až diky pronikání metod environmentální archeologie do terénního výzkumu sledujeme v posledním desetiletí soustředění na hospodářské zázemí vesnic reprezentované plužinou. Jde nejen o soudobé metody dálkového průzkumu Zemé, ale především o kombinované metody datováni dosud opomijených polních systémů. Dalším novým prvkem je detailni rekonstrukce přrrodního prostředi středověké a novověké vsi pomoci archeobotanických metod. Projekt „Identifikace a ochrana dochovaných pozůstatkü historických plužin“ si tak klade za cill poskytnout informace a vyvinout nástroje směrujici $k$ jejich ochraně. Výsledky poskytuji podklad pro kvalifikovanou ochranu historických polnich systémů, ale i jejich pochopeni v kontextu vývoje historické krajiny. Text je přehledem problematiky v rámci současných znalostí o plužině a agrárních terasách a je zaměren především na poznatky krajinné archeologie a krajinné ekologie.
\end{abstract}

Klíčová slova: terasové pole - plužina - environmentální archeologie - krajinná archeologie - krajinná ekologie.

Archaeological research into field systems and agrarian terraces as the phenomena of the historical landscape in the Czech Republic

\begin{abstract}
Field systems, a historical term as well as distinct landscape elements both in the Czech Republic and the whole central Europe, have until recently been a somewhat neglected part of the historical cultural landscape in terms of archaeology. The interest of archaeologists centred, in particular, on the inner areas of deserted villages. Thanks to the introduction of the methods of environmental archaeology into field survey, the last decade has seen the concentration on the economic hinterland of villages represented by field systems. These methods involve not only the modern ones of long-distance land survey but especially the combined methods of dating the hitherto marginalized field systems. Another new element is the detail reconstruction of the natural environment of medieval and modern-age villages by means of archaeobotanical methods. A project entitled "Identification and preservation of the historic field patterns" seeks to bring information and to develop tools aimed at their protection. The results provide groundwork for the specialist protection of historical field systems, as well as for their understanding in the context of the development of historical landscape. The article offers an overview of these issues within the framework of the current state of knowledge about field systems and agrarian terraces, and predominantly involves information supplied by landscape archaeology and landscape ecology.
\end{abstract}

Key words: terrace field - field systems - environmental archaeology - landscape archaeology - landscape ecology.

\section{Úvod}

Plužina je napříč vědními disciplínami chápána jako souhrn veškerých agrárních ploch zemědělského sídliště. Obecně se plužina charakterizuje jako hospodářsky využitelná část krajiny náležející vesnickému sídlišti; jedná se o souhrn všech polí, luk a pastvin propojených navzájem sítí cest (Štěpánek 1967; Gojda 2000, 187). Někdy je plužina chápána jen jako zemědělsky obdělávaná část zázemí sídliště rozdělená na jednotlivé parcely a nezahrnuje louky, pastviny a obecní a dominikální lesy (Dohnal 2003, 10). Základní jednotkou plužiny je polní parcela neboli pole. Vyšší jednotkou pak svazek parcel. Jimi se rozumí ohraničený soubor vedle sebe ležících parcel, které mají řadu společných znaků: rozměry, velikost, tvar, směr průběhu, topografický vztah k usedlosti (s napojením nebo bez napojení na usedlost). Nejcharakterističtějším znakem plužiny 
je mezní pás, který velmi napomáhá při rekonstrukci zaniklých plužin nebo jejich částí. Mezní pásy byly často tvořeny kamenným valem či nasypanou hlínou s př́měsí kamenů (Černý 1979), na které se postupně navázala dřevinná či keřovitá zeleň, čímž se tvar plužiny v krajině zafixoval.

Definice do značné míry vychází z pojetí plužiny v tradici německé historické geografie (Krüger 1967; Born 1979; Denecke 1979; Sperling 1982). Tato škola chápe plužinu (v němčině die Flur) jako historicky se vyvíjející strukturu držby vesnického sídla, jejíž dnešní podoba je výsledkem řady dynamických, ekonomických a majetkových změn. Plužina byla v německé literatuře od 19. století velkým tématem, do značné míry zatíženým etnickým nábojem. V posledních desetiletích se však pozornost soustřed’ovala na sledování geneze plužiny a následnosti blokových, tratových a záhumenicových typů. Soudobé bádání již nesleduje etnickou linii, ale staví na historických okolnostech sídelních aktivit (Žemlička 2014, 114-115). Na německé školy agrární historie a historické geografie navázalo i národopisné a historické bádání v Čechách (Pohl 1934-1935; Dohnal 2003; Klír 2003), sledující v historickém kontextu problematiku specifického regionu. Přehledné dílo o plužině však dosud neexistuje. Transformace krajiny, jejímž klíčovým prvkem je právě geneze plužiny, je sledována především prizmatem středověké kolonizace (Klápště 2005; 2012; Žemlička 1997, 2014).

V krajinné ekologii je pak plužina chápána jako významný krajinný prvek zvyšující ekologickou stabilitu zemědělské krajiny a zároveň jako významný prvek historický a estetický. V současné krajině je plužina identifikovatelná díky jejím nejviditelnějším projevům, mezním pásům a agrárním terasám, často pokrytým zapojeným dřevinným porostem (Pittnerová 2008; Kuča 2014). Ty tvoří hranici mezi parcelovanými poli a hrají v krajině důležitou roli (Burel 1996; Baundry et al. 2000; Quin-Burel 2002; Bayer-Beneš 2004). Kromě toho zmírňovaly a nadále zmírňují erozi půdy, zadržují vodu a živiny, čímž plní významnou jak ekologickou, tak i krajinotvornou funkci (Poschlod 2015).

Archeologie sledující zemědělská sídla středověku a novověku se majoritně věnovala intravilánu vsí. Objektem zájmu byla nejčastěji zaniklá stř̌edověká sídla. To bylo způsobeno hlavně orientací bádání na archeologizovaná jádra zaniklých vsí jako na předmět tradičního archeologického pojetí místa s koncentrovanými archeologickými nálezy (Klápště 1978; Smetánka 1988; Klápště 2005, 163-283; Belcredi 2006), i když s tehdy inovativním pohledem na krajinu vesnického zázemí v duchu britské paleoekonomické výzkumné tradice a francouzského historického bádání (Beresford-Hurst 1991; u nás srov. Smetánka 1992). Systematický výzkum středověkých osad v českých zemích reprezentuje tehdy ojedinělý př́iklad zaniklé středověké vesnice Pfaffenschlag u Slavonic (Nekuda 1975). Pozoruhodné je, že už tehdy byly do výzkumu Pfaffenschlagu nasazeny metody archeobotaniky a paleoekologie, a to do té míry, že nastolily mezi specialisty měřítko, jak k problematice přistupovat. Spojení výzkumu intravilánu a př́rodního prostředí středověké vesnice tím dostalo jasnou formu a kvalitní badatelský obsah spočívající v zasazení středověké vesnice do krajinného kontextu.

V osmdesátých a devadesátých letech se díky rozvoji letecké archeologie počíná zájem archeologů upínat ke krajině jako subjektu výzkumu. Krajina se začala zkoumat jako celek. Vzniklo nové odvětví oboru - krajinná archeologie. Kolébkou této specializace se stala Velká Británie. V teoretickém rámci britské krajinné archeologie našlo pevné místo i téma středověkých polních systémů. Krajinná archeologie zde navázala na bohatou tradici výzkumu tzv. keltských polí (celtic fields). Detailní analýza polních systémů vycházela v Británii z rozdílu mezi tzv. keltskými a vícepolními systémy (Gray 1959). Za prvního krajinného archeologa, alespoň co se technického př́stupu týče, je považován již o generaci starší O. G. S. Crawford (1886-1957). Právě on objevil potenciál leteckých snímků a na nich patrného členění agrární krajiny. Jeho mapy vycházející z leteckého snímkování ukazovaly starší vrstvu tzv. keltských polí překrytých mladšími „saskými“ poli podlouhlého typu ohraničenými mezními pásy (Denecke 1979, 410-411; Kuna et al. 2004, 238).

Samotný termín krajinná archeologie zakořenil až v 70. letech 20. století jako pojmenování pro směr, kterým se ubírali badatelé v poválečné Anglii (Aston 1985; 2007; Roberts 1996; u nás 
srov. Gojda 2000, 76-89). Silným elementem krajinné archeologie se stalo její fenomenologické pojetí (Bender 1992; Ingold 1993), které paralelně vstoupilo i do české vědy o krajině (Beneš 1993; Beneš-Brůna 1993; Sádlo 1993). Ve stejné době jsme byli v archeologii zemědělského pravěku svědky koncentrace výzkumu sídelních areálů (Neustupný 1986; Beneš 1993; Gojda 2000). Tento teoretický koncept, vycházející opět především z britské inspirace (Aston 1985; 2007; Roberts 1996), chápe zemědělské sídlo v krajině nejen jako geografickou jednotku s pozůstatky architektury a př́slušnou mobilní materiální kulturou, ale hlavně jako kontinuální prostor s koncentrací obytné a hospodářské funkce $\mathrm{v}$ jádru areálu, který postupně přechází do zahradních, polních, pastevních a exploatačních zón (Kuna et al. 2004). Od 90. let 20. století začala být krajinná archeologie populární i v domácí archeologii. Na počátku 90. let vznikl česko-britský projekt Ancient Landscape Reconstruction in Northern Bohemia, který sledoval sídelní strukturu a podobu kulturní krajiny severních Čech na základě celoplošných povrchových sběrů. Specifikem bylo chápání krajiny jako historického interaktivního prostoru a archeologického záznamu v krajině jako palimpsestu (Beneš-Zvelebil 1999; Gojda 2000, 76-89). Jednou z nevýraznějších pozorovaných vrstev tohoto palimpsestu bylo pravěké a raně středověké zemědělské zázemí sídelních jader, předcházející vrcholně středověké zemědělské transformaci.

V prvním desetiletí nového století pronikly do archeologie ve větší míře geoarcheologické a bioarcheologické metody. Environmentální archeologie postupně zaujala významné místo nejen v terénní archeologické praxi, ale stala se žádanou metodologií i v akademickém výzkumu (Branch et al. 2005). Řada dříve jen náhodně nebo výjimečně použitých metod a konceptů byla v české archeologii uplatněna rovněž, zejména po vydání knihy Nedestruktivni archeologie (Kuna et al. 2004). Právě tato publikace alespoň částečně systematizovala př́stup $\mathrm{k}$ fenoménu plužiny (Kuna et al. 2004, 237-296) jako součásti chronologické vrstvy kulturní krajiny středověku a raného novověku.

Na rozdíl od koncentrace badatelského úsilí do archeologizovaných jader vsí v druhé polovině minulého století sledujeme v posledním desetiletí soustředění výzkumu právě na hospodářská zázemí středověkých a novověkých sídlišt'. Hlavní otázky výzkumu byly zaměřeny především na využití krajiny, přičemž byly použity tradiční historicko-geografické metody k rekonstrukci polních systémů, luk a pastvin. Mezi tyto metody paří např́ílad písemné záznamy, toponyma, literární zdroje, historické mapy a ilustrace (Dohnal 2003; 2006). K výzkumu extravilánů přispěl i rychlý nástup nových metod dálkového průzkumu Země (Gojda-John edd. 2013; Holata et al. 2018) a environmentální archeologie (Houfková et al. 2015; 2019; Hejcman et al. 2013a; 2013b), díky níž lze efektivně řešit otázky datování, funkce a charakteru hospodářského zázemí historických sídel, ke kterým plužina organicky náleží. Především se ukazuje, že přímý terénní archeologický výzkum plužiny umožňuje řešit i otázky datování vzniku sídlišt’ a jejich funkčních charakteristik (Kinnaird et al. 2017; Janovský-Horák 2018; Quirós-Castillo-Nicosia 2019).

V posledních několika desetiletích se na tradiční polní systémy a jejich ekologickou hodnotu začali soustředit badatelé v oboru krajinné ekologie, kteří zdůrazňují vysokou environmentální hodnotu těchto částí krajiny (např. Konold et al. 1996; Plieninger et al. 2016). G. Beaufoy a kol. (1995) zdůrazňují, že pomalé tempo antropogenních změn v těchto krajinách zaručuje jejich vysokou ekologickou stabilitu, a konstatují, že tradiční zemědělské technologie podporují vysokou strukturální diverzitu vegetace a existenci vysokého procenta př́rodě blízkých ekosystémů. M. F. Heath a G. M. Tucker (1995) také poukázali na schopnost tradičních polních systémů dlouhodobě odolávat změnám př́rodních podmínek, což je v době klimatické změny činí zvlášt' cennými př́iklady dlouhodobě udržitelné praxe (Hampicke 2006).

Tradiční systémy polí ohraničených mezními pásy (v anglické literatuře je používán pojem hedgerows) zaujímají v krajinně ekologické literatuře významné místo. Řada studií diskutuje roli mezních pásů jako koridorů nebo v některých případech i jako matrix v zemědělské krajině (např. Pollard et al. 1974; Forman-Baudry 1984; Forman-Godron 1986). Studie z tohoto oboru zaměřené na středověké polní systémy jsou zatím poměrně vzácné a úzce lokalizované, ale existují. K. Molnárová a kol. (2008; 2008a) poukázali na vysokou krajinně ekologickou hodnotu mezních 
pásů (pozůstatků středověkých a raně novověkých plužin) a dokumentovali výraznou ztrátu jejich plochy, konektivity a dalších krajinně ekologických ukazatelů v náhodně vybraných segmentech v Plzeňském kraji. V souladu s obecnými trendy vývoje evropské kulturní krajiny (např. Plieninger et al. 2016) zanikla část historických krajinných struktur vlivem intenzifikace zemědělské výroby, část vlivem sukcesních procesů v opuštěných částech plužiny. K. Zímová a kol. (2013) se zabývali vývojem krajinné matrix a mezních pásů relativně dobře zachované plužiny zaniklé obce Malonín. I zde však konstatovali poměrně výrazné změny krajinného pokryvu směřující k zániku této historické krajinné struktury.

Spojení archeologie plužin s jejich ekologickým výzkumem vytváŕí nový, dosud ne zcela probádaný prostor. Ten nabízí nejen archeologické zacílení na otázku vzniku, funkce a často i zániku původní agrární funkce plužin, ale řeší významnou roli reliktů středověké a raně novověké krajiny jak v současné společnosti, tak i v udržení ekologické stability krajiny. Archeologický výzkum plužiny tak dostává novou, nečekanou roli. Více se tomuto tématu věnoval např́íklad R. Schreg (2014).

Následující odstavce se pokouší systematizovat současné znalosti o středověké a raně novověké plužině z hlediska environmentální archeologie a krajinné ekologie a naznačit nové možnosti jejich výzkumu zejména ve spojení obou teoretických rámců a metodologických postupů. Text si neklade nárok na detailní a zevrubný popis všech typů př́stupů. Jeho cílem je popsat soudobý stav znalostí a připravit prostor pro informace o probíhajícím výzkumu pokrývajícím celé území České republiky.

\section{Polní systémy a jejich rozšíření}

Geografické a geologické charakteristiky území, půda a klima, ale především lidské ekonomické a sociální potřeby zemědělských populací určovaly převládající typ polních systémů v jakémkoli regionu. Ačkoliv jsou předmětem našeho zájmu v minulosti vzniklé plužiny a polní systémy, musíme na ně nahlížet v kontextu soudobé krajiny. Proto je vždy třeba studovat středověké polní systémy jako součást aktuálně př́tomné krajiny (Moorhouse-Bond 2016). Kontrast mezi původní funkcí plužin a jejich současnou rolí je atraktivním interpretačním prostorem, který je užitečné zaplnit. Abychom dobře pochopili význam a funkční proměny středoevropských polních systémů, bude vhodné je zařadit do nejširšího geografického kontextu.

Mezi velmi časté typy polních systémů patří terasová pole, polní systémy charakteristické viditelným ohraničením svých parcel a tzv. open fields. V globálním měřítku jsou první dva zmíněné systémy krajinným fenoménem již od neolitu, existují napříč celým světem v regionech s výškovým členěním terénu (Agnoletti et al. 2015) a nejsou specifické pro archeologická období či historické periody. Asijská terasová pole, pro která se použivá termín paddy fields, existovala již od samotného nástupu zemědělství v mladší době kamenné (Iyiama et al. 2005; Beneš 2018). $\mathrm{Na}$ americkém kontinentu byly $\mathrm{v}$ předkolumbovské době vytvářeny polní systémy typu chinampa nebo waru-waru (Pregil-Volkman 1999), které jsou v současnosti znovu objevovány a obnovovány. V Evropě vznikala pole ohraničená mezními pásy zpravidla od středověku, př́klady krajin zachovaných do současnosti jsou francouzské krajiny bocage (Baundry et al. 2000) s převážně šachovnicovitou strukturou nebo české plužiny (Molnárová et al. 2008a; 2008b; Sklenička et al. 2009), jejichž pole mají většinou charakteristický podlouhlý tvar (obr. 1). Protože jsou všechny výše jmenované krajiny místně specifické, jejich názvy se v anglické literatuře zpravidla nepřekládají a používají se v originální jazykové verzi (např. Lieskovský et al. 2014; Wiezik et al. 2017).

Pravěké a raně středověké polní systémy, které vzniku vrcholně středověkých a raně novověkých krajinných útvarů předcházely, jsou v České republice velice málo poznány. Existuje totiž kritický nedostatek přímých dokladů polí a hranic mezi nimi, což je na našem území dáno mnoha faktory. Především se jedná o kumulativní efekt dlouhodobého pravěkého až novověkého zemědělství v úrodných oblastech nížin a o dopad moderní extenzivní orby na př́padné relikty pravěkých až raně středověkých polních systémů (Dreslerová 2016). Na rozdíl od jiných evropských krajin, 


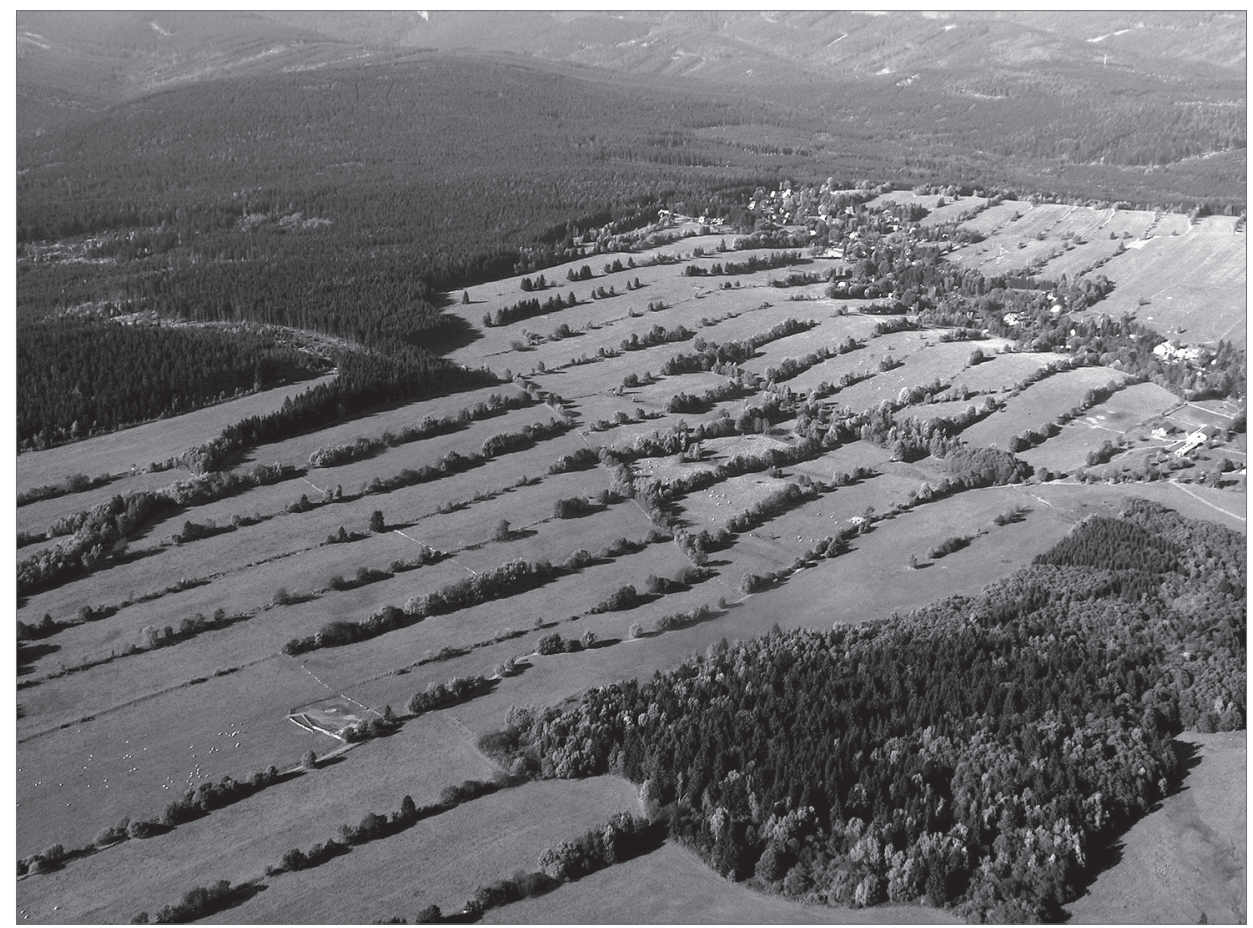

Obr. 1. Letecký pohled na plužinový systém u Nové Vsi (Dolní Moravice, okr. Bruntál). Foto Markéta Hendrychová. Abb. 1. Flugansicht auf das Flursystem bei Nová Ves (Dolní Moravice, Bezirk Bruntál). Foto Markéta Hendrychová.

kde se dochovaly pravěké polní systémy ve velkém měřítku (Nielsen et al. 2018), nedisponují české země tímto typem agrárních památek. Ty jsou datovány v severozápadní Evropě do mladší doby bronzové a doby železné a jsou souhrnně nazývané celtic fields. Kořeny zájmu o tento fenomén, a tím i o polní systémy obecně, lze vypozorovat především na Britských ostrovech (Aston 1985; 2007). Budování „pravoúhlých“ sítí pravěkých polí je zde prokázáno již z doby bronzové. Pravěká pole se na mnoha místech Britských ostrovů a v severozápadní Evropě dobře dochovala a budila již záhy značnou pozornost (Fleming 1988). Bádání o pravěkých polích probíhalo souběžně se studiem mladších, převážně středověkých polních systémů.

Na mnoha místech světa, většinou v souvislosti se vznikem historických státních útvarů (Varotto et al. 2019), proběhla zásadní transformace krajiny spočívající v zemědělském využití podhorských a horských území s větší dynamikou reliéfu. Terasová pole se stavěla za účelem obhospodařit zemi ve vyšších polohách a na strmých svazích. Podstatnou vlastností těchto polí bylo, vedle základní agrární funkce, zachytit více vody, podpořit zavlažování a redukovat půdní erozi (Wei et al. 2016). V Evropě se stavěla terasová pole pro pěstování vína a oliv (např. oblast Cinque Terre v Itálii, ale i mnoho dalších), zatímco v Asii, Africe a Americe se terasy využívaly k pěstování obilovin, např́ílad kukurrice, rýže, čiroku a prosa v závislosti na oblasti (Varotto et al. 2019; Tarolli et al. 2019). Obecně zřejmě platí, že budování terasových polí koreluje s populačním růstem a se snahou účinně zemědělsky využít i méně efektivní prostor.

V Asii patří mezi typická terasová pole paddy fields, na nichž se pěstuje rýže. Příznačná jsou především pro japonskou oblast Satoyama, která je charakteristická zalesněným a kopcovitým terénem. Celkově tyto polní systémy pokrývají 67 \% území Japonska (Iiyama et al. 2005; Fukamachi 2017). Terasová pole se nacházejí i v Jižní Americe, především v horských oblastech Peru, Ekvádoru a Bolívie, kde sloužila k pěstování brambor, kukuřice a merlíku chilského 
(Goodman-Elgar 2008). Můžeme je spatřit i v Africe, především v horských oblastech Etiopie, Ugandy a Rwandy (Tarolli et al. 2014).

V Evropě se terasová pole vyskytují jak v mediteránní oblasti, tak v alpském regionu a jejich původ sahá až do doby železné (Stanchi et al. 2012). Výzkum je spjat především s jejich zánikem, který měl za následek erozi půdy (García-Ruiz-Lana-Renault 2011; Dotterweich 2013). Výzkumy teras byly provedeny např́iklad v Řecku (Krahtopoulou-Frederick 2008; Bevan-Conolly 2011), Portugalsku (Nunes et al. 2016), v oblasti Pyrenejí (Seeger-Ries 2008) a ve Slovinsku (DragoPerko 2017; Momirski 2019).

Ve střední Evropě a potažmo i v České republice nejsou terasová pole, vyjma některých viničných oblastí, tak výrazná jako v oblastech uvedených výše (Štefunková-Hanušin 2019). Jedná se zde o polní systémy, které jsou situovány ve svažitém terénu a jejichž pásy sledují vrstevnici. V takovém případě jsou tyto pásy odděleny terasováním. Pozemkové úpravy při budování zemědělských teras výrazně a zásadně ovlivnily obraz středoevropské krajiny. Hlavním účelem budování terasových polí bylo zvýšení retenční schopnosti tehdy nově budovaných polních systémů (k tomuto aspektu Bayer-Beneš 2004), dalším důvodem byla snadnější manipulace orebným náčiním při obhospodařování, například částečnou eliminací sklonu. Důležitý je sociální princip vzniku vrcholně středověké plužiny ve vztahu k morfologii terénu a rozdíl mezi nížinnými a horskými oblastmi. V nížině původní plužinu často setřel následný složitý vývoj, zatímco $\mathrm{v}$ podhorských a horských oblastech sledujeme parametry plužiny kontrastněji. Její organizace do dlouhých pásů, často $\mathrm{v}$ délce až dva kilometry, měla pozitivní efekt na organizaci hospodářovy zemědělské aktivity. Vše potřebné měl hospodář pohromadě a mohl regulovat vztah zasívaných ploch k úhoru, pastvinám a loukám (Žemlička 2014, 110-114).

Druhým fenoménem indikujícím zemědělské využíání krajiny jsou polní systémy, jejichž parcely jsou ohraničené mezními pásy. V západní Evropě se jim říká bocage či hedgerows. Pole s mezními pásy nejsou pouze evropským fenoménem. Nacházejí se naprríklad i v Africe, kde tyto rostlinné ,ploty“ chrání zahrady obklopující vesnice (Lauga-Sallenave 1997). Rozšířená jsou i v Jižní Americe - Ekvádoru a Bolívii -, kde oddělují jednotlivé pastviny. V Severní Americe byla vytvořena prvními evropskými osadníky, kteří si upravovali půdu podle svých zvyklostí z Evropy (Hewes 1981; Sutton 1985).

Typickým projevem těchto polních systémů jsou mezní pásy. Obecně jsou definovány jako řada keřů a/nebo stromů, spontánně rostoucích i vysázených, v jejichž prostoru je patrný lidský zásah, který kontroluje a brání jejich expanzi do přilehlých polí. Nejčastěji se jedná o hranice polí a jsou součástí managementu zemědělských aktivit (Baundry et al. 2000). Nejstarším rostlinným druhem využívaným pro stavbu těchto pásů byl hloh jednosemenný (Crataegus monogyna), dále se využivala vrba (Salix spp.) či líska (Corylus avellana) (Hoskins 1955; Baudry et al. 2000) a na území střední Evropy trnka obecná (Prunus spinosa).

Funkce mezních pásů nespočívala pouze v ohraničení pozemků, měly i mnohem důležitější úlohu v krajině. Především ovlivňovaly fyzické, chemické i biologické procesy, jako například pohyb vody (odvodňování, zavlažování) nebo částic půdy (snížení eroze). Dále mohly sloužit jako ochrana před větrem a v neposlední řadě také poskytovaly zdroj palivového dřeva, materiál na nářadí (např̀. vrbové proutí) a možnost sběru léčivých bylin (např. kopřiv; Merot et al. 1999; McCollin et al. 2000; Elsayed Ali 2015). V dnešní době, kdy už většina mezních pásů neplní svůj původní účel, jsou ceněny pro svoji historickou, vizuální, a především ekologickou hodnotu.

Největší pozornost byla polním systémům věnována ve Velké Británii, kde dominovaly především polní systémy typu open fields (Pollard et al. 1974; Rackham 1986). Jedná se o rozsáhlé systémy orných polí, která mají otevřený charakter, jednotlivé parcely nejsou obklopeny ploty, zdmi ani jinými viditelnými hranicemi. Typickým projevem těchto polí byly rovné pásy parcel. Rozdělení pole na paralelní linie bylo tím nejjednodušším způsobem. Tento tvar měl však i agrárně-technický důvod. Tím bylo používání těžkého a špatně ovladatelného pluhu taženého voly (Renes 2016). Původ otevřených polí je datován již k 10. století, které se zdá být dobou transformace. Od 13. století docházelo, prredevším v jádrových oblastech, k fragmentaci vlastnictví 
půdy, které se vázalo na populační růst. V časném 14. století dosáhly open fields vrcholu rozkvětu. Během vrcholného středověku se na Britských ostrovech udály zásadní změny, při kterých začaly staletí dlouhé procesy jejich přeměny. Tyto procesy vedly k postupnému mizení otevřených polních systémů na Britských ostrovech (Renes 2016). Od 16. století se začala pole ohraničovat. Tím končilo tradiční právo na společnou půdu, která tak byla striktně rozdělena vlastníkům. Byla to doba, kdy došlo ke změně z kolektivního na individuální systém využívání půdy (Rackham 1986).

\section{Vývoj, terminologie a typologie plužinových systémů v České republice ${ }^{1}$}

Mezi 11.-15. stoletím došlo v Evropě ke změnám v sociální, kulturní a ekonomické sféře. Změny se týkaly i českých zemí a mimo jiné znamenaly kolonizování nových oblastí a transformaci celkového rázu krajiny. První fáze proměny probíhala od 11. do poloviny 13. století (Žemlička 1997, 275-277). V sociální sféře se vyznačovala společenskou stratifikací a vznikem pozemkové šlechty. V 11. a 12. století prováděl přemyslovský stát přesuny obyvatelstva především do nejúrodnějších oblastí země. Do poloviny 13. století osídlení pokrylo prakticky všechny zemědělsky příhodné oblasti u nás. Druhá fáze osidlování trvající do 14. století posunula kolonizační aktivitu do vyšších nadmořských výšek vrchovin, pahorkatin a do podhůří. Vzniklé vesnice v těchto oblastech měly nejčastěji tvar dlouhé údolní (lineární) lánové vsi, která se táhla podél toků, a k ní přiléhající pásové záhumenicové plužiny. V tomto období docházelo k výrazné agrární transformaci krajiny, která se vyznačovala výrazným odlesňováním za účelem rozšíření zemědělsky využívané plochy (Černý 1979; Gojda 2000; Löw-Míchal 2003; Klápště 2005; 2012; Sádlo et al. 2008).

Od vrcholného středověku docházelo k radikální proměně zemědělského systému, kdy se z př́ilohového zemědělství přecházelo na trojpolní systém. S tímto systémem přišla i inovace orebné techniky a proměna zemědělské krajiny, která se rozčlenila do protáhlých polí s viditelnými hranicemi jednotlivých pozemků (Sádlo et al. 2008; Klápště 2012). Od 15. století začalo docházet $\mathrm{k}$ redukci osídlení a k populačnímu úbytku. Jednalo se o celoevropský fenomén související s válečnými událostmi a morovými epidemiemi, který přesáhl i do století šestnáctého. Toto období bylo charakteristické zánikem mnoha vsí (Maur 1996; Měřínský 2008; Holata 2014). Další vlna redukce přišla po třicetileté válce. Mnoho vesnic bylo zničeno a neobnoveno, jejich pozemky byly zabrány vrchnostenskými dvory a došlo tak k prvnímu výraznému scelování plužin. Během novodobé kolonizace horských oblastí v 16. a 17. století a především v 18. století došlo k zakládání tak zvaných „parcelačních“ plužin, které se vyznačovaly geometricky mechanickým členěním plochy na užší či širší, ale krátké úseky (Kuča 2014).

Velikost a tvar plužin byl ovlivněn mnoha různými faktory - charakterem terénu, kvalitou půdy, rozvojem zemědělských výrobních nástrojů, které ovlivňují způsob obdělávání půdy a také vnitřním vývojem společnosti i hospodářských poměrů (Vermouzek 1982; Boháč 1986). Ústředním pojmem při odvozování velikosti plužiny je lán, jednotka obdělané i neobdělané půdy, respektive pojem lánová soustava (Graus 1957, 134-135). František Graus upozorňuje na neustálenost velikosti lánu a na fakt, že se velikost lišila podle oblasti. Geomorfologie terénu určovala průběh lánů, často zformovaných do zemědělských teras. Je patrná tendence probíhání mezních pásů ve směru vrstevnic. Zamezovalo se tak odplavování půdy při deštových srážkách, ale účel byl i praktický - lépe se oralo, sklízelo a svážela úroda. I přesto však většina mezních pásů, především lánových plužin, je k vrstevnicím kolmá (Černý 1979).

Mezi půdorysem vsi a typem plužiny existuje bezprostřední, neopominutelný vztah (Němčenko 1970). Na vztah mezi sídlem a plužinou upozorňují také Klír (2008); Kuna et al. (2004); Nekuda (2002); Černý (1973); Láznička (1946, 1956); Ř́kovský (1939) aj. Oproti některým půdorysům plužiny je však půdorys vesnice mnohem stabilnější (Votrubec 1980). U plužiny lze pozorovat tvary pravidelné, ukazující na plánovitý vznik a vývoj, a tvary nepravidelné, svědčící

1 Projekt Identifikace a ochrana dochovaných pozůstatků historických plužin byl nastaven tak, že vychází ze sekundární literatury a typologie E. Černého. Primární literatura - srov. nap̌r. Krüger 1967; Uhlig-Lienau 1978; Verhulst 1995 s lit. 
o samovolném vývoji. Plužiny tedy nelze brát jako izolovaný jev a je nezbytně nutné posuzovat je z mnoha hledisek. Jsou to př́rodní poměry, poloha (nížina, vrchovina), teritorium, v němž se plužina nachází (staré nebo mladé sídelní území), způsob obhospodařování, zemědělské nářadí a dějinné období, v němž plužina vznikla (Žemlička 2014). Při respektování všech těchto zřetelů je nutno si v prvé řadě uvědomit, že plužina není útvar neměnný (Vermouzek 1982), proto její členění do různých typů má v principu formálně třídící charakter a jen zprostředkovaně odráží její historický vývoj.

Plužinu lze tedy členit do řady typů podle toho, jak v ní byla rozdělena pozemková držba jednotlivých usedlostí v rámci sídla, a podle toho, v jakém terénu se rozkládala (Löw-Míchal 2003). Existuje několik možností, jak lze plužiny dělit. Láznička (1946) dělí plužiny např́íklad na sedm typů, Löw s Míchalem (2003) na šest typů. Černý (1973) představil klasifikaci typově nejširší, a to sedm základních typů, přičemž ještě plužinu záhumenicovou dělí na další tři podtypy. Vzhledem ke skladbě jednotlivých částí plužiny v terénu pak uvedl další tři podtypy klasifikace, a to plužinu kompaktní, plužinu nesoudržnou rozštěpenou a plužinu nesoudržnou rozptýlenou (tab. 1, obr. 2). Z tohoto důvodu bylo v rámci studie uvažováno následující členění dle Černého (1973):

- Plužina úseková (obr. 2:1)

- Plužina scelených úseků (obr. 2:2)

- Plužina dělených úsekũ (obr. 2:3)

- Plužina délková (obr. 2:4)

- Plužina tratová (obr. 2:5)

- Nepravá tratová plužina (obr. 2:6)

- Plužina záhumenicová - typické lineární lánové vsi (obr. 2:7)

- Plužina záhumenicová - pásová a klínová (obr. 2:8)

- Plužina záhumenicová - paprsčitá (radiální) (obr. 2:9)

Samotný pojem záhumenicová plužina je problematický, nebot' i např́íklad část délkové plužiny má záhumenicový charakter. V některé literatuře se tak začíná používat přesnější termín lánová plužina, která se dále dělí na plužiny lineární a radiální (paprsčitou). Pojem lánová plužina odkazuje na častý výskyt pojmu lán v písemných pramenech (laneus: Graus 1953, 326-327). Pásová a klínová forma záhumenicové plužiny je pak kombinací obou uvedených typů a nebývá zahrnuta do základní typologie (Kuča 2014). Kategorizace na lánové lineární a radiální vsi a k nim př́islušné plužiny byla použita například v Atlasu krajiny ČR, kde jsou v mapě zachyceny všechny lánové vsi a plužiny na našem území (Hrnčiarová-Mackovčin-Zvara 2009).

Tab. 1. Jednotlivé typologie plužin. Podle Láznička 1946; Černý 1973; 1979; Löw-Míchal 2003; uspořádala B. Kottová. Tab. 1. Die einzelnen Flurtypen nach Láznička (1946), Černý $(1973,1979)$ und Löw-Míchal (2003); erstellt von B. Kottová.

\begin{tabular}{|c|c|c|}
\hline LÁZNIČKA (1946) & ČERNÝ (1973; 1979) & LÖW-MÍCHAL (2003) \\
\hline úseková & úseková & úseková \\
\hline scelených úseků & scelených úseků & dominikální \\
\hline dělených úseků & dělených úseků & nepravá tratová \\
\hline délková & délková & délková \\
\hline trat'ová & trat'ová & trat'ová \\
\hline scelená & nepravá tratová & \multirow[t]{2}{*}{ záhumenicová } \\
\hline záhumenicová & $\begin{array}{l}\text { záhumenicová } \\
\text { - lesní lánové vsi } \\
\text { • pásová a klínová } \\
\text { - paprsčitá }\end{array}$ & \\
\hline
\end{tabular}


Utváření hranic plužiny bylo značně závislé na terénu. V krajinách vertikálně bohatě členěných byly hranice vytvářeny nebo ovlivňovány převážně geografickými útvary (svahové hřbety, rozvodí, vodní toky a okraje potočních nebo říčních teras). V krajinách rovinatých byly hranice plužin nejčastěji vytvářeny uměle (Žemlička 2014, 115). Umělou hranici tvořily např́iklad cesty nebo okraj sousední plužiny (Černý 1979). Z hlediska kompaktnosti dělí Černý (1973) plužiny do tří kategorií:

- Plužina kompaktní (obr. 2:10)

- Plužina nesoudržná - rozštěpená (obr. 2:11)

- Plužina nesoudržná - rozptýlená (obr. 2:12)

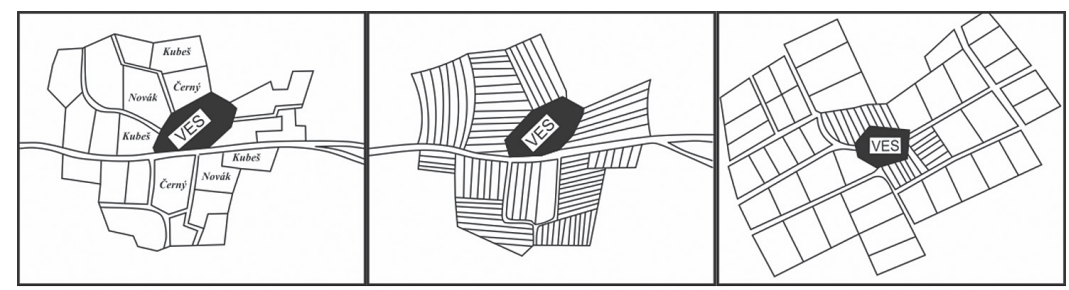

1 úseková

2 scelených úseků

3 dělených úseků

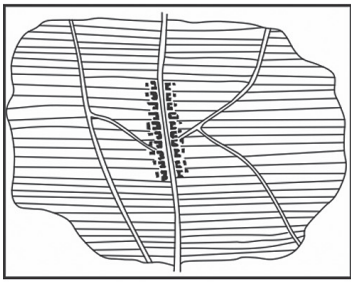

4 délková

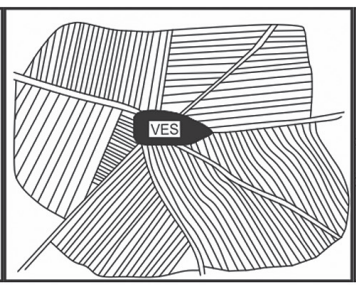

5 trat'ová

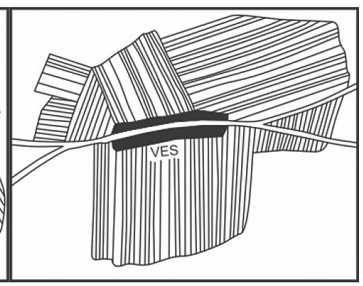

6 nepravá trat'ová

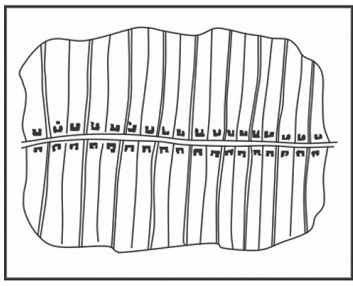

7 záhumenicová

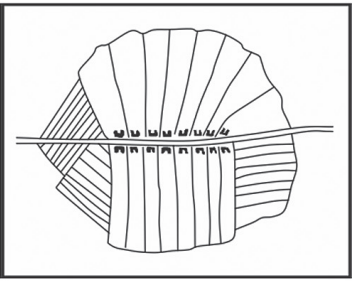

8 záhumenicová

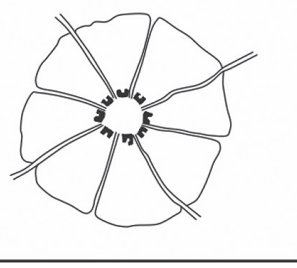

9 záhumenicová

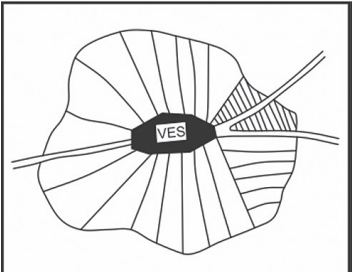

10 kompaktní

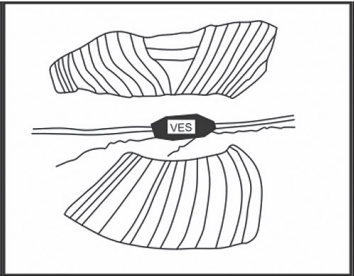

11 nesoudržná

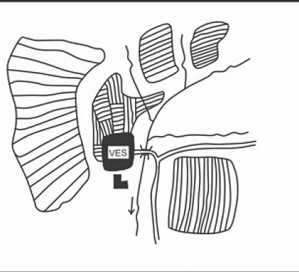

12 nesoudržná

Obr. 2. Typy plužinových systémů. Podle E. Černého uspořádala B. Kottová.

Abb. 2. Flursystemtypen. Von B. Kottová erstellt nach E. Černý. 


\section{Základní přehled archeologických výzkumů plužin v České republice ${ }^{2}$}

Pro pochopení současného stavu archeologického výzkumu plužin v České republice je nejprve nutné zmínit vývoj problematiky vesnic a vesnického osídlení v historické vědě. Po druhé světové válce se začal rozvíjet historiografický zájem o středověké venkovské osídlení. Jako stěžejní dílo této doby je uváděn pětisvazkový slovník Mistní jména v Čechách od A. Profouse (1947; 1949; 1951; 1957), který vyšel v letech 1947-1960. Jako analogie tohoto díla pak v roce 1970 vyšel první díl Mistních jmen na Moravě a ve Slezsku a v roce 1980 následoval díl druhý (Hosák-Šrámek 1970; 1980). Zásadní je rovněž dvousvazkové dílo Františka Grause o dějinách venkovského lidu v Čechách. Dílo, až poplatné tehdejší ideologii, přineslo zásadní faktografický materiál k porozumění středověké vesnici a zemědělství (Graus 1953; 1957). Pro Moravu se stalo důležité jméno Zdeňka Lázničky, jehož práce zde silně ovlivnily studium středověkého osídlení. Ve svém díle Typy venkovského osídlení na Moravě (Láznička 1946) jako první sepsal typologii plužin. V 50. letech byly položeny základy archeologie vrcholného středověku. Jedno z jejich hlavních témat se zaměřovalo na vesnické osídlení, a především na zaniklé středověké vesnice (Čapek-Holata 2017). Ve stejné době byly zahájeny i terénní průzkumy zaniklých středověkých sídel. Cenné poznatky obecně k zaniklým vesnicím a jejich plužinám pak shromáždil Ervín Černý (Černý 1973; 1979). Zaměřil se především na oblast Drahanské vrchoviny, kde se zabýval identifikací, klasifikací, charakteristikou a rekonstrukcí plužiny v krajině. Celkově podal ucelený přehled o rozdělení plužin a zaniklých vesnic do několika kategorií a každému typu vsi přiřadil určitý typ plužiny. Z historicko-geografického hlediska se na zaniklé vsi a plužiny zaměřili např́ílad Miroslav Štěpánek $(1967 ; 1968)$, Zdeněk Boháč (1986) či Josef Žemlička (1974; 1980).

Jeden z prvních archeologických výzkumů v Čechách, při kterém došlo $\mathrm{k}$ identifikaci plužin, byl proveden Zdeňkem Smetánkou a Janem Klápštěm na zaniklých středověkých vesnicích na Černokostelecku. I přesto, že zde dlouhodobě probíhal povrchový průzkum, byly středověké plužiny zachyceny jen omezeně. Plužiny byly kolem vesnic rozloženy v závislosti na terénní situaci a měnily se v rámci všech etap hospodářského vývoje. Podle indikačních skic map stabilního katastru ze 30. a 40. let 19. století převládaly na Černokostelecku tratové plužiny, které byly výsledkem radikální přestavby osídlení během 13. a 14. století. Stopy starších polí jsou zachovány jen výjimečně (Klápště 1978; Klápště-Smetánka 1979; Smetánka-Klápště 1981). Na Moravě, jako jeden z prvních, systematicky zkoumal intravilán i extravilán zaniklé středověké vsi Pfaffenschlag Vladimír Nekuda. Zde byla na základě indikační skici z roku 1828 rekonstruována podoba plužiny. Byla zachycena záhumenicová plužina obdélného tvaru, která byla mnohonásobně delší než širší, což bylo způsobeno primárně půdorysným uspořádáním vsi a typem plužiny, druhotně i zavedením pluhu. Na západní straně vsi byla identifikována plužina doplňková, která je na indikační skice označena jako malé zahrádky (Nekuda 1975, 164). V dalších letech pak přibyly další výzkumy zaniklých vsí a jejich extravilánů, např́íklad Mstěnice u Hrotovic (Nekuda-Nekuda 1997), Konůvky (Měchurová 1997) či Bystřec u Jedovnic (Belcredi 2006).

Do archeologie na přelomu 20. a 21. století vstoupily nové metody umožňující prospekci krajiny a možnou identifikaci (nejen) středověkých polních systémů. V první řadě šlo především o metody leteckého průzkumu, o které se výrazně zasadili Martin Gojda a Zdeněk Smrž pro území Čech, na Moravě Jaromír Kovárník a Miroslav Bálek (Gojda 2000, 120). Letecká prospekce a dokumentace podnítila, podobně jako kdysi ve Velké Británii, studium krajiny a krajinné archeologie.

Druhým odvětvím, které se $\mathrm{v}$ archeologii stalo fenoménem v prvních deseti letech 21. století, byl dálkový průzkum Země, konkrétně letecké laserové skenování povrchu (LIDAR). Aplikace této metody se stala jedním z nejefektivnějších způsobů průzkumu krajiny a umožnila tak detekci reliktů minulých lidských aktivit jak v lesním prostředí, tak v otevřené krajině

2 Ucelený přehled vývoje výzkumu středověkého osídlení nejnověji shrnuli L. Čapek a L. Holata (2017, 267-320). 
(Gojda-John-Starková 2011). Mimo jiné se tato metoda využívá i k detekci zaniklých vesnic a jejich plužin (Malina 2015). Poprvé bylo letecké laserové skenování využito pro zaniklé vesnice a jejich extravilány na Plzeňsku, Rokycansku a Černokostelecku. Jednalo se o otestování možností lidarového mapování antropogenních tvarů reliéfu v krajině a zhodnocení jeho efektivity. Např́íklad na Černokostelecku se pomocí LIDARu identifikovaly i méně nápadné komponenty, jakými byly zaniklé cesty a zbytky plužin (Gojda-John-Starková 2011). O něco později byl LIDAR použit např́iklad pro zmapování zaniklých vesnic Prochod a Žd'ár ve Velechvínském polesí v okrese České Budějovice (Gojda-John 2013, 150-159) a pro plužiny zaniklé vsi Spindelbach v Krušných horách, kde bylo s jeho pomocí identifikováno třináct parcel (Horák-Klír 2017). Kromě samotné identifikace vesnic a jejich extravilánů lze letecké laserové skenování využít jako podpůrnou metodu pro další analýzy, např́íklad za účelem modelování eroze půdy na stř̌edověkých polích (Holata et al. 2018).

První samostatný prŕmý výzkum agrárních reliktů byl v České republice realizován na Šumavě v oblasti Vlachova Březí na katastru obce Dolní Kožlí. Zkoumané relikty kamenných hrazení datovaných do pozdního středověku a raného novověku vznikly při pracích na zemědělské ploše. Jednalo se o typ hrazení s př́íkopem, který sloužil k regulaci zvěře na polích (Beneš et al. 1999; Kuna et al. 2004, 280-282). V prŕípadě Dolního Kožlí byla nastavena metoda relativního datování „bývalé“ orné půdy pomocí keramických fragmentů. Toto datování bývalé ornice, dnes přerostlé lesem nebo proměněné v pastvinu, bylo později použito ve výzkumu Malonína (Houfková et al. 2015). Metoda spočívala ve vyhodnocení artefaktů, tzv. hnojných střepů (mannuring scatters) typologickou charakteristikou a v sestavení otevřených intervalů ze 12 vzorkovacích sondáží. Intervaly vymezovaly zhruba období, po které byla půda ve zkoumaném polním systému ornicí. To bylo v případě Dolního Kožlí v 15.-17. století. Výzkum Dolního Kožlí u Vlachova Březí nastolil otázku korelace tzv. malého klimatického optima s orným využíváním vyšších nadmořských poloh v daném období a následně jejich zániku v době ochlazení v tzv. malé době ledové (Beneš et al. 1999).

Do výzkumu polních systémů postupně v tomto končícím desetiletí pronikly další obory environmentální archeologie založené především na pedologii a geochemii. Pedologický průzkum byl proveden např́íklad na zaniklé vsi Kří. Cílem chemického rozboru půdy bylo zjistit, zda krátkodobé osídlení (ne delší než 60 let) může nevratně změnit chemické složení půdy a zda se tato př́ípadná změna může odrazit na druhovém složení rostlin. A naopak, zda se podle složení půdy dá identifikovat bývalé osídlení a užívání půdy v zaniklých stř̌edověkých vesnicích. Výsledky analýzy $\mathrm{z}$ této studie potvrdily domněnku, že využívaní krajiny $\mathrm{v}$ minulosti mohlo způsobit změny ve složení půdy a v druhovém spektru rostlin a že tuto metodu lze využít i pro odhalení bývalého osídlení v zalesněném prostředí (Hejcman et al. 2013a). Další geochemické analýzy půdy byly provedeny např́íklad na plužině zaniklé středověké vesnice Lovětín na Českomoravské vrchovině (Horák et al. 2018), pro plužinu ZSV Hol východně od Prahy (Janovský-Horák 2018) a Spindelbach v Krušných horách (Horák-Klír 2017). Pro poslední zmíněnou zaniklou ves byla také provedena kompletní environmentální rekonstrukce, která mimo jiné zaznamenala výrazné změny ve složení vegetace vlivem lidského využívání horských okrajových oblastí během vrcholného střredověku (Houfková et al. 2019).

Z hlediska hydrologie byla zkoumána středověká pole na Šumavě. Účelem hydropedologického výzkumu bylo objasnit vliv tehdejších krajinných úprav na vodní režim půdy a také, jak smysl úprav přetrval do dnešní doby. Byly pozorovány některé souvislosti, zřejmě obecného charakteru. Bylo zjištěno, že plužiny ve svahu bývají odděleny terasami, které ovlivňují povrchový a podpovrchový odtok vody, a že různé typy polních systémů mají odlišný vliv na dobu zadržení vody v půdním profilu. Radiální plužina má výrazně menší retenční funkci než plužina tvořená terasovými poli (Bayer-Beneš 2004). První detailní multi-proxy analýza polního systému v České republice byla provedena pro zaniklou středověkou ves Malonín u Frantol na Prachaticku (obr. 3). V roce 1995 zde proběhl záchranný archeologický výzkum (Beneš 1995) a v roce 2001 byly z jednoho terasového pole plužiny odebrány vzorky na archeobotanickou analýzu rostlinných 


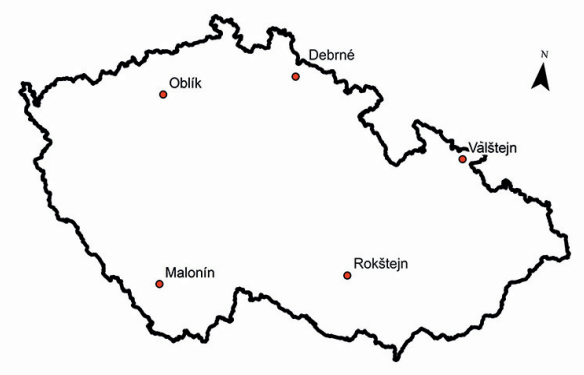

Obr. 3. Mapa České republiky s vyznačenými zkoumanými plužinovými systémy. Vizualizace J. Bumerl.

Abb. 3. Karte der Tschechischen Republik mit eingezeichneten untersuchten Flursystemen. Visualisierung J. Bumerl.

mikrozbytků. Rozbor pylů a fytolitů prokázal př́tomnost cereálií $\mathrm{v}$ půdním profilu dnešní pastviny (Bayer-Beneš 2004). Systém v Maloníně začal být dlouhodobě sledován. Později zde byla provedena analýza land-use vývoje s použitím map stabilního katastru a leteckých snímků (Zímová et al. 2013). Následoval přímý výzkum tělesa meze. Účelem multi-proxy analýzy bylo zjistit stáří polního systému. Byly srovnávány historické dokumenty a mapy s chronologiemi založenými na archeologických nálezech, radiokarbonovém datování a datování za pomoci izotopů olova ${ }^{210} \mathrm{~Pb}$ a cesia ${ }^{137} \mathrm{Cs}$. První písemný záznam o vsi Malonín pochází z roku 1349. Spálený organický materiál z nejnižší vrstvy profilu, který byl př́mo spjat s lidskými aktivitami, byl radiokarbonově datován do let 1154-1271, a předchází tedy první písemnou zmínku o vsi zhruba o 150 let (Houfková et al. 2015). Tento značný rozpor mezi písemnými prameny a exaktním datováním terasy byl jedním ze stimulů systematického šetření velkého souboru dat v České republice, jeho účelem bylo objasnit princip a rozsah zpožd’ování písemných pramenů oproti archeologickému datování (Fanta et al. 2020).

\section{Projekt Identifikace a ochrana dochovaných pozůstatků historických plužin}

Systematické použití metod environmentální archeologie a krajinné ekologie vedlo k myšlence většího projektu, který by zkoumal různé typy plužin např́ič Českou republikou. Tomuto úsilí se věnuje projekt z programu na podporu aplikovaného výzkumu a experimentálního vývoje národní a kulturní identity (NAKI II). Projekt (2018-2022) si klade za cíl poskytnout informace a vyvinout metody a nástroje směřující $\mathrm{k}$ ochraně historických plužin, které patří na území ČR k nejcennějším, ale také nejopomíjenějším historickým kulturním elementům. Cílem je poskytnout celorepublikové mapové podklady pro kvalifikovanou ochranu historických polních systémů. V rámci projektu probíhá vektorové mapování všech dochovaných pozůstatků historických plužin v jednotlivých krajích ČR. Historický původ mapovaných struktur je potvrzen pomocí historicko-geografické analýzy. Mapovány jsou struktury se třemi nebo více dochovanými mezními pásy. Výsledné mapové dílo bude obsahovat informaci o několika tisících území s různě dochovanými fragmenty historických plužin a sídel, $\mathrm{k}$ nimž jsou tyto fragmenty vázány, a s popisem jejich relevantních atributů. V rámci vybraných katastrů budou získány detailní archeologické a paleoekologické informace, zahrnující datování a popis stavebního a funkčního charakteru vybraného mezního pásu. Projekt rovněž zahrnuje rekonstrukci a zachycení dynamiky vývoje vegetačního krytu na základě pylové analýzy u vybraného polního systému.

Projekt je zaměřen na pozůstatky historických plužin v otevřené krajině, které jsou fixovány mezními pásy, zpravidla zarostlými dřevinnou vegetací. Tyto struktury jsou v zemědělské krajině nositeli jak historických, tak i estetických, ekologických a krajinotvorných hodnot. Do projektu nejsou zahrnuty relikty zaniklých plužin uchované v lesních terénech. Ty vyžadují zvláštní metodický př́istup, nebot' jsou ohroženy jiným způsobem (nejčastěji devastací lesní těžbou). Výjimku tvoří prŕípady, kdy je část rozsáhlejšího celku zachována částečně v otevřené krajině, částečně je zarostlá lesem. V těchto případech bude zmapována a popsána celá dochovaná struktura.

Na území České republiky se v různé míře dodnes dochovalo několik tisíc fragmentů plužinových systémů. Jejich charakter byl bliže popsán ve studii Sklenička et al. (2009), jejich středověký původ pilotně potvrzen v př́ípadě Malonína exaktním datováním ve studii Houfková 
et al. (2015) a raně novověký původ v případě Valštejna (Šitnerová et al. 2020). Nezastupitelnost mezních pásů fixujících původní hranice pozemků byla sledována ve studii Sklenička et al. (2017). Mapování v rámci grantového projektu je zaměřeno na identifikaci dochovaných pozůstatků krajinné struktury historických plužin, jejich typizaci a analýzu relevantních atributů (např. výměra segmentu, land-use, rytmus mezí, celistvost mezí, srůstání mezí apod.). Podkladem pro analýzy jsou mapy stabilního katastru, Základní báze geografických dat České republiky (ZABAGED), současné ortofotosnímky a snímky digitálního modelu reliéfu (LIDAR). Analýzy jsou doplněny terénním šetřením.

$\mathrm{V}$ rámci projektu bylo $\mathrm{k}$ archeologickému a paleoekologickému výzkumu vybráno pět plužinových systémů reprezentujících různé typy plužin v různých typech krajiny Č́R (nížiny, pahorkatiny, horské prostředí; obr. 3). Účelem archeologické části projektu je systémy exaktně datovat a dále získat údaje, které by umožnily detailnější popis a vegetační rekonstrukci. Prvním vybraným systémem v rámci projektu byla záhumenicová plužina obce Valštejn v Nízkém Jeseníku, vzdálená 6,5 km na severozápad od Města Albrechtic. Jedná se o čistě zemědělskou horskou obec ve Slezsku v nadmořské výšce $517-550 \mathrm{~m} \mathrm{n}$. m. Obec Valštejn byla podle písemných pramenů založena krátce před rokem 1618 Hanušem Kryštofem z Valdštejna, stejně jako blízká Stará a Nová Dlouhá Voda (Alt- a Neu-Langwasser). Obec tedy patří k raně novověkým založením. Součástí je i vedle ležící Ztracená Voda (Verlorenwasser). Plužinové systémy, které se zde dochovaly (Šitnerová et al. 2020), patří k velmi rozsáhlým a nejlépe dochovaným na území České republiky (obr. 4).

Pro účely vytyčení sondy a odebrání vzorků k environmentálním analýzám byl vybrán druhý mezní pás plužiny kopírující vrstevnici a ležící severovýchodně od Valštejnského potoka v nadmořské výšce 540 metrů. Hranici terasy vymezovala jihozápadním směrem zídka. Vytyčená sonda byla 11 metrů dlouhá a metr hluboká. Z každých deseti centimetrů byl odebírán vzorek pro archeobotanické rozbory a z celkového profilu pak vzorky pro environmentální analýzy a ke stanovení datace. Během sondáže byl zjištěn intencionálně vytvořený kamenný podklad bezprostředně navazující na zídku. Po jeho odkrytí v rámci prostoru sondy bylo s překvapením evidováno, že se jedná o promyšlenou konstrukci složenou z větších plochých kamenů, které do

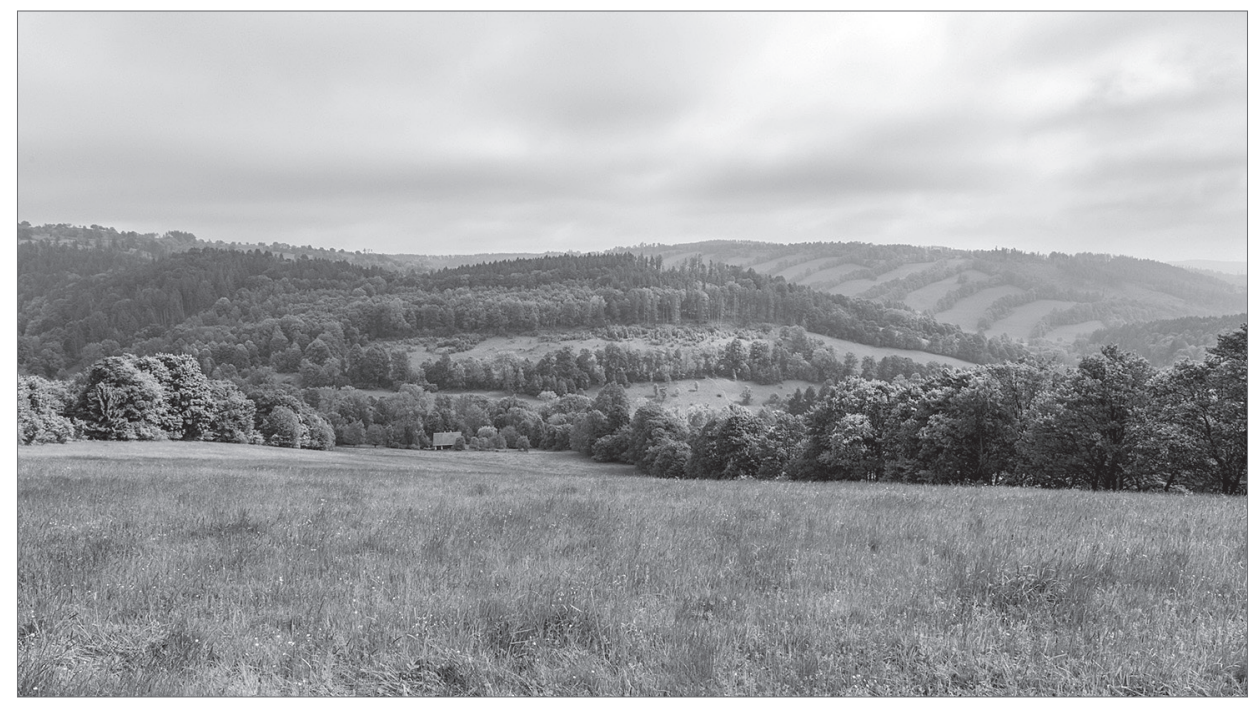

Obr. 4. Pohled na plužinový systém v Nízkém Jeseníku, Valštejn, Město Albrechtice. Mezní pás zkoumaný v roce 2018 je ve střední části snímku. Foto T. Jůnek.

Abb. 4. Blick auf ein Flursystem im Niederen Gesenke, Valštejn, Stadt Albrechtice. Der im Jahr 2018 untersuchte Grenzstreifen befindet sich im mittleren Teil der Aufnahme. Foto T. Jůnek. 
sebe zapadají a jsou vyskládány v několika řadách pod sebou. Prostor mezi jednotlivými řadami je vysypán menšími kameny. Celá konstrukce má podpěrný účel, který konstrukci jistí před sesuvem půdy (obr. 5). Radiokarbonová data získaná z profilu mezního pásu odpovídají době založení vesnice. Předpokládá se, že zpoždění datování písemnými prameny oproti skutečnému založení je v 17. století již minimální (Fanta et al. 2020).

Druhým zkoumaným plužinovým systémem jsou úsekové plužiny (Riezner 2011; dle Kuča 2014 plužiny tratové) v oblasti kolem Oblíku v Českém středohoří patřící k obcím Raná a Chraberce (obr. 6). Jedná se o reziduální systém, který leží v českém termofytiku v oblasti, která

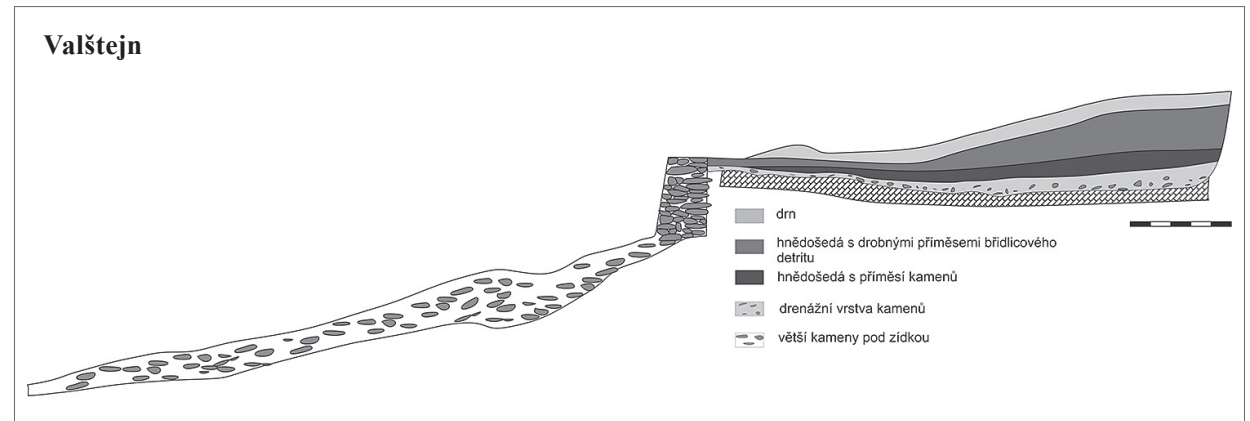

Obr. 5. Řez mezním pásem, Valštejn. Vizualizace J. Bumerl.

Abb. 5. Schnitt durch einen Grenzstreifen, Valštejn. Visualisierung J. Bumerl.

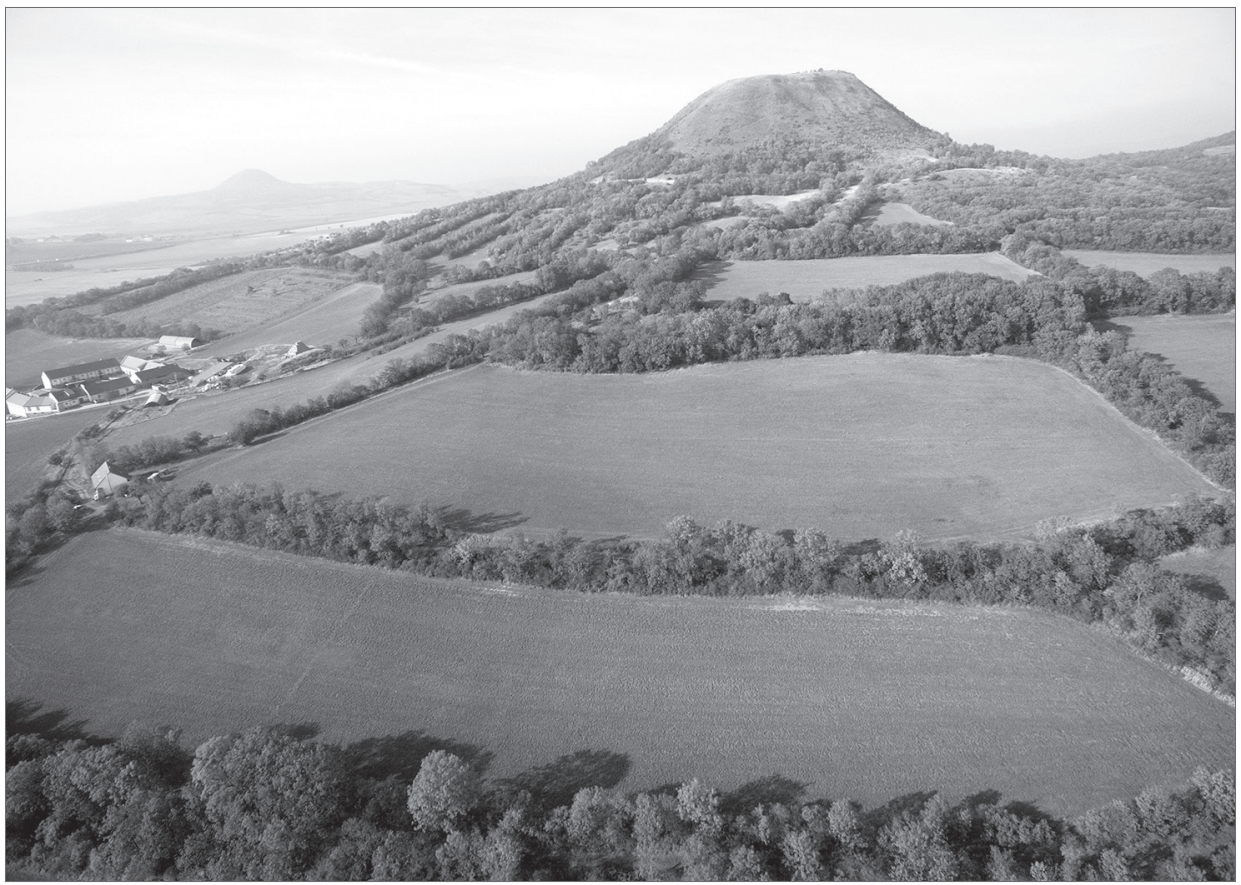

Obr. 6. Pohled na plužinový systém v okolí Oblíku, České stř̌edohoří. Mezní pás zkoumaný v roce 2018 je v dolní části snímku. Foto Jan Lohniský, JUROS s. r. o., Ústí nad Labem.

Abb. 6. Blick auf das Flursystem in der Umgebung von Oblík, Böhmisches Mittelgebirge. Der im Jahr 2018 untersuchte Grenzstreifen befindet sich im unteren Teil der Aufnahme. Foto Jan Lohniský, JUROS s. r. o., Ústí nad Labem. 
prošla od 50. let 20. století procesem výrazného scelování pozemků. Hora sopečného původu Oblík s vrcholem v nadmořské výšce 509 metrů a její úboční partie chránily tento systém před zničením, jež postihlo velké plochy okolní krajiny, kde se nyní nacházejí velmi rozsáhlé lány. Zde byl vybrán nejnižší horizontální mezní pás plužiny v nadmořské výšce 270 metrů. Skrz mezní pás byla vytyčena sonda o délce deseti metrů a hloubce $160 \mathrm{~cm}$. I zde se odebíraly vzorky pro plavení a environmentální analýzy. Stejně jako tomu bylo u výše zmíněné plužiny ve Valštejně, byla také zde odkryta stabilizační kamenná konstrukce i pod mezním pásem v oblasti Oblíku (obr. 7 a 8). Systém několika řad vyskládaných plochých kamenů s meziprostorovým výsypem byl velmi podobný tomu z Nízkého Jeseníku.

Třetí zkoumanou lokalitou je nepravá trat’ová rozptýlená plužina kolem hradu Rokštejna v katastrálním území Panská Lhota města Brtnice v nadmořské výšce 450 metrů (obr. 9). První zmínka Panské Lhoty je datována k roku 1234. Hrad Rokštejn byl údajně založen roku 1270. Vybraným mezním pásem byla vytyčena sonda o délce sedmi metrů. U severního okraje sondy se začalo podloží objevovat již v hloubce $60 \mathrm{~cm}$ a postupně se svažovalo až do konečné hloubky jednoho metru. Těsně nad hranou a v prostoru hrany se v úrovni $70 \mathrm{~cm}$ začaly objevovat malé kamínky a pod nimi větší množství velkých kamenů, nenesly však známky intencionálního

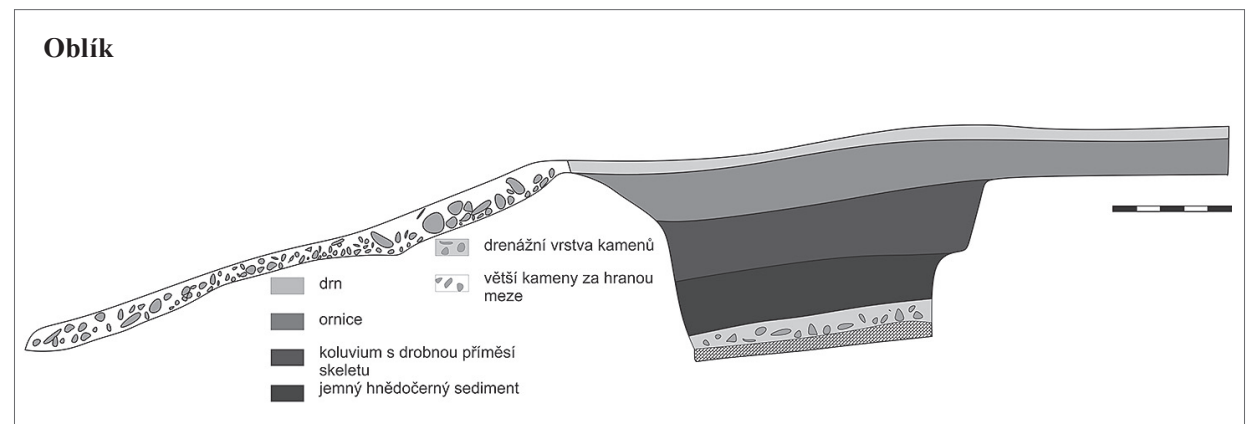

Obr. 7. Řez mezním pásem, Oblík. Vizualizace J. Bumerl.

Abb. 7. Schnitt durch einen Grenzstreifen, Oblík. Visualisierung J. Bumerl.

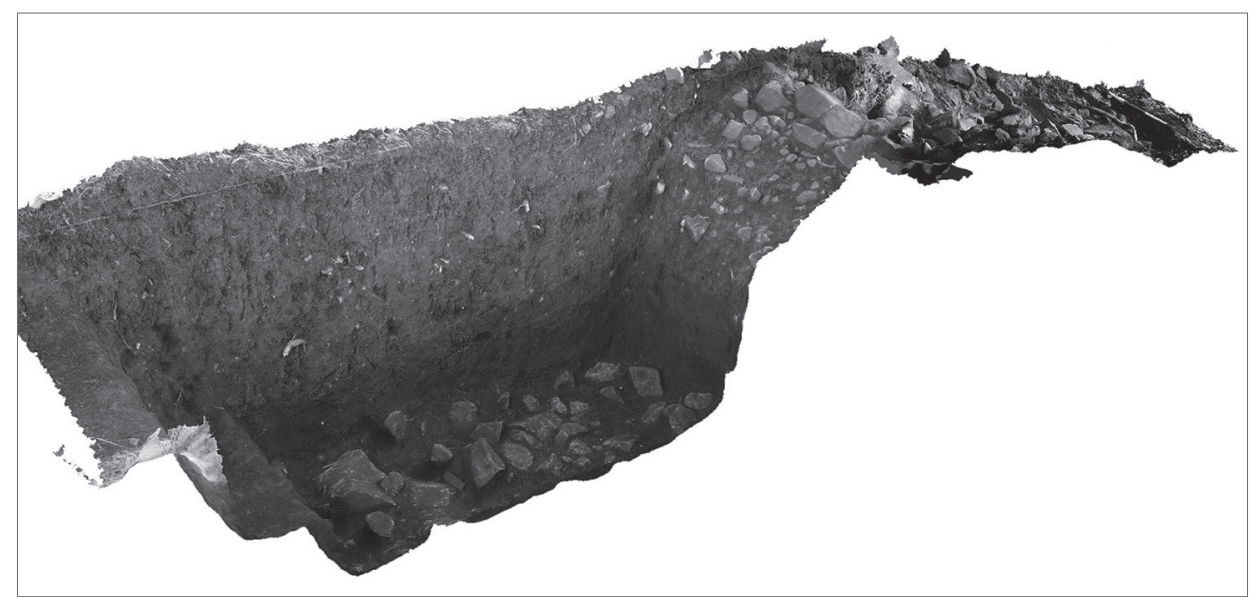

Obr. 8. 3D model sondy v mezním pásu plužinového systému pod Oblíkem. Foto a vizualizace J. Bumerl.

Abb. 8. 3D-Modell des Sondierschnitts im Grenzstreifen des Flursystems unterhalb von Oblík. Foto und Visualisierung J. Bumerl. 
uložení (obr. 10). Zde se situace lišila od předchozích mezních pásů zkoumaných ve Valštejně a na Oblíku. Je tedy možné, že se může jednat o starší typ plužiny. Tuto domněnku potvrdí až výsledky radiokarbonového datování a dalších relevantních metod.

Poslední vybraný plužinový systém pokrývá katastrální území bývalé vesnice Debrné u města Trutnova (obr. 11). Poprvé je ves zmiňována v roce 1260 a zanikla po druhé světové válce vysídlením německého obyvatelstva. Zkoumaný mezní pás záhumenicové plužiny se nachází v nadmořské výšce 575 metrů. Mezním pásem zde byla vytyčena sonda o délce 5 metrů. I v tomto př́ipadě byla odkryta kumulace valounových kamenů, která byla účelně vyskládána, podobně jako v př́ípadě Oblíku a Valštejna. Vzhledem k doposud velice nízkému počtu takto zkoumaných

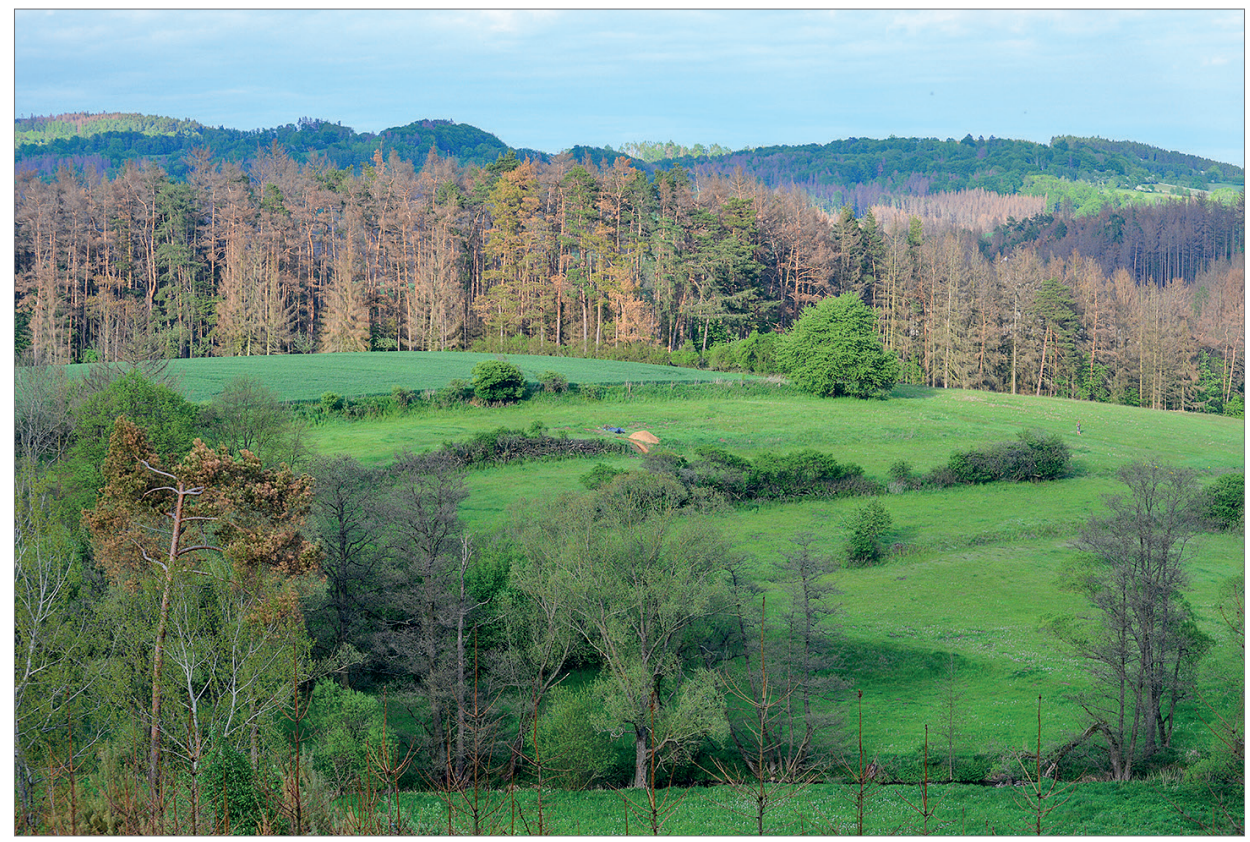

Obr. 9. Pohled na plužinový systém u hradu Rokštejna, Panská Lhota, Brtnice. Zkoumaný mezní pás je ve střední části snímku. Foto T. Jůnek.

Abb. 9. Blick auf das Flursystem bei Burg Rokštejn, Panská Lhota, Brtnice. Der untersuchte Grenzstreifen befindet sich im unteren Teil der Aufnahme. Foto T. Jůnek.

\section{Rokštejn}

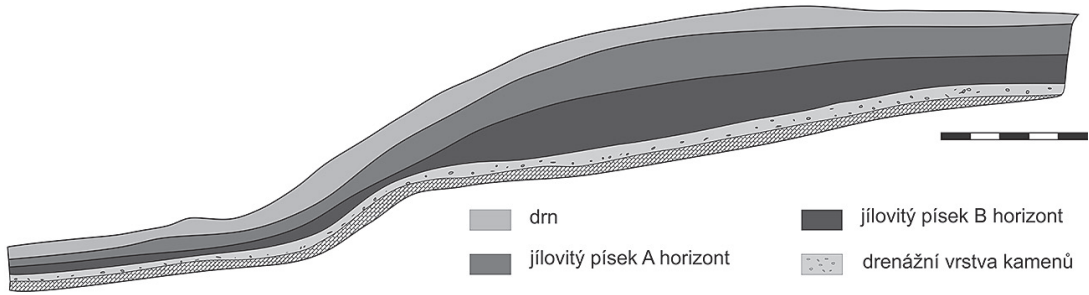

Obr. 10. Řez mezním pásem, Rokštejn. Vizualizace J. Bumerl.

Abb. 10. Schnitt durch den Grenzstreifen, Rokštejn. Visualisierung J. Bumerl. 


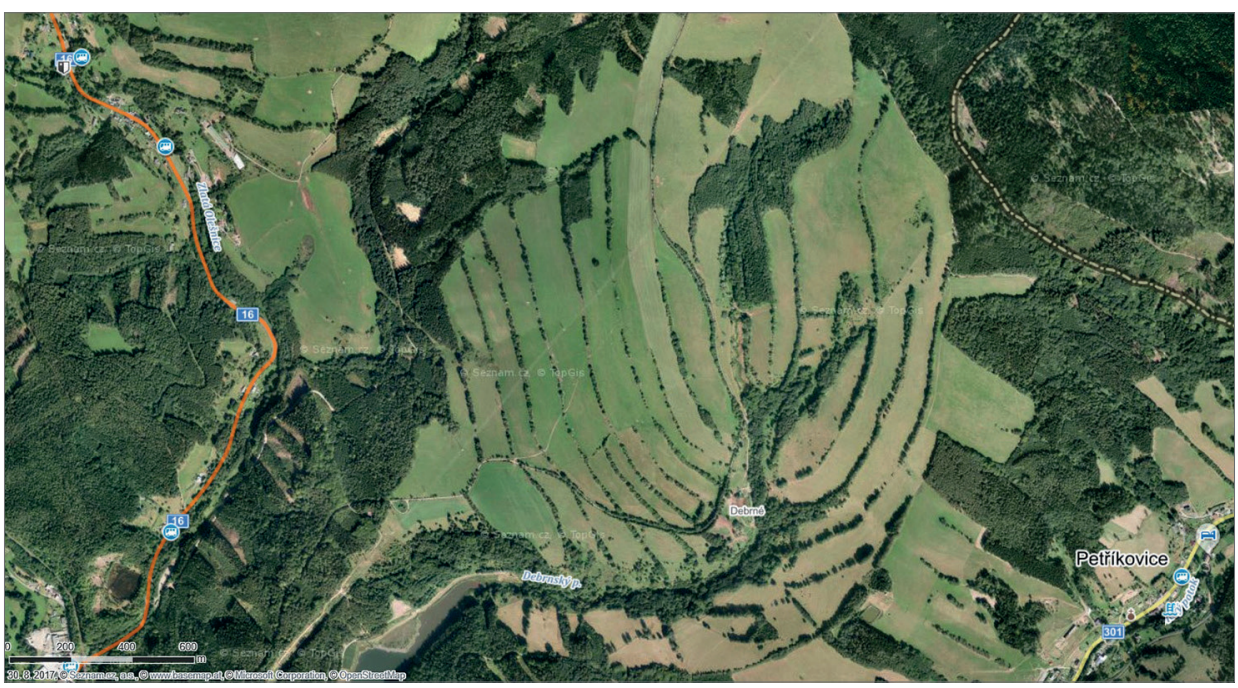

Obr. 11. Pohled na plužinový systém zaniklé vsi Debrné, Trutnov. Zdroj mapy.cz.

Abb. 11. Blick auf das Flursystem an der Dorfwüstung Debrné, Trutnov. Quelle mapy.cz.

mezních pásů a teras lze považovat existenci intencionální konstrukce terasy pod ornicí a akumulační vrstvou za důležité obecné zjištění.

\section{Závěr}

Polní systémy a jejich nejtypičtější prvky, zemědělské terasy a mezní pásy, se vyskytují po celém světě všude tam, kde si vyšší populační hustota obyvatelstva vynutila využití i těch částí krajiny, kde by jinak agrární produkce nebyla technicky možná. Terasová pole měla a mají řadu dílčích funkcí, z nichž nejdůležitější jsou vyrovnání terénu, zadržení a bilance vláhových poměrů a erozní zábrana. Z hlediska ekologie krajiny jsou plužiny se svými mezními pásy důležitým prvkem zvyšujícím konektivitu a pestrost biotopů.

Archeologický výzkum plužinových systémů se v České republice odehrával především v kontextu studia středověkých a novověkých vesnických sídlišt'. Terénní odkryvy řešící otázku funkce a datování byly spíše náhodné. Až poslední desetiletí přineslo nové možnosti jejich přímého terénního studia, a to na bázi nových možností leteckého laserového snímání, archeobotaniky, izotopového geochemického studia a exaktního datování. Projekt Identifikace a ochrana dochovaných pozůstatkủ historických plužin kombinuje metody velkoplošné dokumentace, mapování a základní klasifikace agrárních systémů v otevřené krajině. Archeologický výzkum vybraných systémů se pak soustř̌edí na plužiny v různých typech krajin České republiky. Dosud provedené odkryvy odhalily detaily vnitřní konstrukce terasových polí na Šumavě, v Nízkém Jeseníku, Českém středohoří a v Podkrkonoší. Na př́íkladu koncentrovaně a dlouhodobě zkoumané plužiny v Maloníně se ukazuje, že kombinací archeobotanických metod a izotopového datování lze účinně vyřešit otázku vzniku terasového pole. Samostatnou kapitolou je změna land-use polních ploch a jejich transformace na pastviny během novověku, zejména vzhledem ke klimatickým a ekonomickým faktorům.

Článek vznikl za podpory grantu: Identifikace a ochrana historických plužin - Identification and preservation of historic field patterns NAKI II - DG18P02OVV060. 


\section{Literatura}

AGNOLETTI, M. et al., 2015: Agnoletti, M.-Conti, L.-Frezza, L.-Santoro, A., Territorial Analysis of the Agricultural Terraced Landscapes of Tuscany (Italy): Preliminary Results, Sustainability 7, 4564-4581. https://doi.org/10.3390/su7044564

ASTON, M., 1985: Interpreting the Landscape. Landscape archaeology in Local Studies. London - New York.

- 2007: Interpreting the Landscape. Landscape Archaeology and Local History. London - New York.

BAUNDRY, J. et al., 2000: Baundry, J.-Bunce, R. G. H.-Burel, F., Hedgerows: An international perspective on their origin, function and management, Journal of Environmental Management 60, 7-22. https://doi.org/10.1006/jema.2000.0358

BAYER, T.-BENEŠ, J., 2004: Středověká terasová pole na Šumavě jako hydropedologický fenomén a archeologický problém, AR LVI, 139-159.

BEAUFOY, G. et al., 1995: Beaufoy, G.-Baldock, D.-Clark, J., The nature of farming. Low intensity farming systems in nine European countries. Inst. for European Environ. Policy. London.

BELCREDI, L., 2006: Bystřec: o založení, životě a zániku středověké vsi. Brno.

BENDER, B., 1992: Theorising landscape, and the prehistoric landscapes of Stonehenge, Man 27, 735-755. https://doi.org/10.2307/2804172

BENEŠ, J., 1993: Ke koncepci krajinné archeologie - On the concept of landscape archaeology, AR XLV, 404-417.

- 1995: Výzkumy archeologického pracoviště Prachatického muzea v roce 1995, Zlatá stezka 2, 159-165.

- 2018: Počátky zemědělství ve Starém světě: Pohled paleoekologie a environmentální archeologie. České Budějovice.

BENEŠ, J. et al., 1999: Beneš, J.-Hrubý, P.-Michálek, J.-Parkman, M., Kamenná hrazení na Hořejším vrchu a vrchu Kokovci u Vlachova Březí. Příspěvek ke studiu agrární krajiny šumavského podhůří, Zlatá stezka 6, 271-296.

BENEŠ, J.-BRU゚NA, V., 1993: Má krajina pamět? In: Archeologie a krajinná ekologie (Beneš, J.-Brůna, V., edd.), 37-46. Most.

BENEŠ, J.-ZVELEBIL, M., 1999: Historical interactive landscape in the hearth of Europe: A case of Bohemia. In: Archaeology and anthropology of landscape (Ucko, J.-Layton, R., edd.), 73-93. London - New York.

BERESFORD, M.-HURST, J., 1991: Wharram Percy: Deserted Medieval Village. Yale University Press.

BEVAN, A.-CONOLLY, J., 2011: Terraced fields and Mediterranean landscape structure: An analytical case study from Antikythera, Greece, Ecological Modelling 222, 1303-1314. https://oi.org/10.1016/j.ecolmodel.2010.12.016

BOHÁČ, Z., 1986: Geneze sídla a plužiny jako pramen k dějinám osídlení, HG 25, 7-52.

BORN, M., 1979: Acker- und Flurformen des Mittelalters nach Untersuchungen von Flurwüstungen. In: Untersuchungen zur eisenzeitlichen und frühmittelalterlichen Flur in Mitteleuropa und ihrer Nutzung 1, Abhandlungen der Akademie der Wissenschaften in Göttingen, Philologisch-Historische Klasse 3/1 (Beck, H.-Denecke, D.-Jankuhn, H., edd.), 310-337. Göttingen.

BRANCH, N. et al., 2005: Branch, N.-Canti, M.-Clark, P.-Turney, P., Environmental Archaeology. Theoretical and Practical Approaches. London.

BUREL, F., 1996: Hedgerows and Their Role in Agricultural Landscapes, Critical Reviews in Plant Sciences 15, č. 2, 169-190. https://doi.org/10.1080/07352689.1996.10393185

ČAPEK, L.-HOLATA, L., 2017: General Overview of Medieval Settlement Research in the Czech Republic: Emergence and Development of the Field, Main Issues and Adoption of Landscape Context, Revista ArkeoGazte Aldizakria 7, 267-320.

ČERNÝ, E., 1973: Metodika průzkumu zaniklých středověkých osad a plužin na Drahanské vrchovině. Zprávy Československé společnosti archeologické při ČSAV 15. Praha.

- 1979: Zaniklé středověké osady a jejich plužiny. Metodika historickogeografického výzkumu v oblasti Drahanské vrchoviny. Praha.

DENECKE, D., 1979: Zur Terminologie ur- und frühgeschichtlicher Flurparzellierungen und Flurbegrenzungen sowie im Gelände ausgeprägter Flurrelikte, Grundzüge eines terminologischen Schemas. In: 
Untersuchungen zur eisenzeitlichen und frühmittelalterlichen Flur in Mitteleuropa und ihrer Nutzung I, 410-440. Göttingen.

DOHNAL, M., 2003: Historická kulturní krajina v novověku. Vývoj vsi a plužiny v Borovanech u Bechyně. Praha.

- 2006: Vesnická sídla a kulturní krajina na Táborsku v 15.-19. století. Praha.

DOTTERWEICH, M., 2013: The history of human-induced soil erosion: Geomorphic legacies, early descriptions and research, and the development of soil conservation - A global synopsis, Geomorphology 201, 9-34. https://doi.org/10.1016/j.geomorph.2013.07.021

DRAGO, K.-PERKO, D., 2017: Terraced landscapes in Slovenia. In: Terraced landscapes (Kladnik, D. et al., edd.). Ljubljana.

DRESLEROVÁ, D., 2016: Fields in prehistoric Bohemia - fact and fiction. In: Agricultural and pastoral landscapes in pre-industrial society: choices, stability and change, ESF EARTH Monograph 3 (Retamero, F.-Schjellerup, I.-Davies, A., edd.), 109-124. Oxford.

ELSAYED ALI, H., 2015: Plant communities in field margins of agricultural landscapes: species distributions, functional traits, and contributions to landscape function. Disertační práce, University of Bayreuth.

FANTA, V. et al., 2020: Fanta, V.-Zouhar, J.-Beneš, J.-Sklenička, P., How old are the historical towns and villages in Centra Europe? A comparsion of the reliability of dating acquired from written sources and from archaeological findings, Journal of Archaeological Science.

FLEMING, A., 1988: Daltmoor Reaves. London.

FORMAN, R. T.-BAUNDRY, J., 1984: Hedgerows and hedgerow networks in landscape ekology, Environmental management 8(6), 495-510. https://doi.org/10.1007/BF01871575

FORMAN, R. T. T.-GODRON, M., 1986: Landscape Ecology. New York, USA.

FUKAMACHI, K., 2017: Sustainability of terraced paddy fields in traditional satoyama landscapes of Japan, Journal of Environmental Management 202, 543-549. https://doi.org/10.1016/j.jenvman.2016.11.061

GARCÍA-RUIZ, J. M.-LANA-RENAULT, N., 2011: Hydrological and erosive consequences of farmland abandonment in Europe, with special reference to the Mediterranean region - A review, Agriculture, Ecosystems and Environment 140, 317-338.

GOJDA, M., 2000: Archeologie krajiny - vývoj archetypů kulturní krajiny. Praha.

GOJDA, M. et al., 2011: Gojda, M.-John, J.-Starková, L., Archeologický průzkum krajiny pomocí leteckého laserového skenování. Dosavadní průběh a výsledky prvního českého projektu, AR LXIII, 680-698.

GOJDA, M.-JOHN, J., edd., 2013: Archeologie a letecké laserové skenování krajiny. Plzeň.

GOODMAN-ELGAR, M., 2008: Evaluating soil resilience in long-term cultivation: a study of pre-Columbian terraces from the Paca Valley, Peru, Journal of Archaeological Science 35, 3072-3086. https://doi.org/10.1016/j.jas.2008.06.003

GRAY, H. L., 1959: English Field Systems. Cambridge.

GRAUS, F., 1953: Dějiny venkovského lidu v Čechách v době předhusitské I. Praha.

- 1957: Dějiny venkovského lidu v Čechách v době předhusitské II. Praha.

HAMPICKE, U., 2006: Efficient conservation in Europe's agricultural countryside: Rationale, methods and policy reorientation, Outlook on agriculture 35(2), 97-105. https://oi.org/10.5367/0000000006777641598

HEATH, M. F.-TUCKER, G. M., 1995: Ornithological value and pastoral farming systems. Farming on the edge: the nature of traditional farmland in Europe, Joint Nature Conservation Committee, Peterborough, $54-59$.

HEJCMAN, M. et al., 2013a: Hejcman, M.-Karlík, P.-Ondráček, J.-Klír, T., Short-Term Medieval Settlement Activities Irreversibly Changed Forest Soils and Vegetation in Central Europe, Ecosystems 16, 652-663. https://doi.org/10.1007/s10021-013-9638-3

HEJCMAN, M. et al., 2013b: Hejcman, M. -Hejcmanová, P.-Hlásná-Čepková, P.-Horák, J.-Karlík, P.-Pavlů, V.-Rosenberg, R.-Součková, K.-Staňková, P.-Stejskalová, M., Environmental Archaeology at the University of Life Sciences Prague - An Application of New Methods for Interdisciplinary Research, IANSA 4, č. 2, 223-231.

HEWES, L., 1981: Early fencing on the western margin of the Prairie, Annals of the Association of American Geographers 71, 499-526. https://doi.org/10.1111/j.1467-8306.1981.tb01371.x 
HOLATA, L., 2014: Změny osídlení v pozdním středověku a raném novověku. Disertační práce, Fakulta filozofická Západočeské univerzity v Plzni.

HOLATA, L. et al., 2018: Holata, L.-Plzák, J.-Světlík, R.-Fonte, J., Integration of low-resolution ALS and ground-based SfM photogrammetry data. A cost-effective approach providing an 'Enhanced 3D Model' of the Hound Tor archaeological landscapes (Dartmoor, South-West England), Remote Sensing 10(9), 1357.

HOLATA, L. et al., 2018a: Holata, L.-Kapička, J.-Světlík, R.-Žížala, D., Risk Management as a Stimulus for a Settlement and Landscape Transformation? Soil Erosion Thread Assessment in the Fields of Four Deserted Villages Based on LiDAR-Derived DEMs and 'USLE'. In: Dynamics in GIscience, GIS Ostrava 2017 (Ivan, I.-Horák, J.-Inspektor, T., edd.), 131-147. [e-book]

HORÁK, J.-KLÍR, T., 2017: Pedogenesis, Pedochemistry and the Functional Structure of the Waldhufendorf Field System of the Deserted Medieval Village Spindelbach, the Czech Republic, Interdisciplinaria Archaeologica 8, č. 1, 43-57.

HORÁK, J. et al., 2018: Horák, J.-Janovský, M.-Hejcman, M.-Šmejda, L.-Klír, T., Soil geochemistry of medieval arable fields in Lovětín near Třešt', Czech Republic, Catena 162, 14-22.

HOSÁK, L.-ŠRÁMEK, R., 1970: Místní jména na Moravě a ve Slezsku. Díl I. A-L. Praha.

- 1980: Místní jména na Moravě a ve Slezsku. Díl II. M-Ž. Praha.

HOSKINS, W. G., 1955: The making of the English Landscape. London.

HOUFKOVÁ, P. et al., 2015: Houfková, P.-Bumerl, J.-Pospíšil, L.-Karlík, P.-Beneš, J.-Bernardová, A.Hrabalíková, M.-Janečková Molnárová, K.-Hejcman, M., Origin and development of long-strip field patterns: A case study of an abandoned medieval village in the Czech Republic, Catena 135, 83-91.

HOUFKOVÁ, P. et al 2019: Houfková, P.-Horák, J.-Pokorná, A.-Bešta, T.-Pravcová, I.-Novák, J.-Klír, T., The dynamics of a non-forested stand in the Krušné Mts.: the effect of a short-lived medieval village on the local environment, Vegetation History and Archaeobotany 28(6), 607-621.

HRNČIAROVÁ, T.-MACKOVČIN, P.-ZVARA, I. et al. 2009: Atlas krajiny České republiky. Praha.

IIYAMA, N. et al., 2005: Iiyama, N.-Kamada, M.-Nakagoshi, N., Ecological and social evaluation of landscape in a rural area with terraced paddies in southwestern Japan, Landscape and Urban Planning 70, 301-313.

INGOLD, T., 1993: The temporality of the landscape, World Archaeology 25, 152-174. https://doi.org/10.1080/00438243.1993.9980235

JANOVSKÝ, M.-HORÁK, J., 2018: Large Scale Geochemical Signatures Enable to Determine Landscape Use in the Deserted Medieval Villages, Interdisciplinaria Archaeologica 9, č. 1, 71-80. https://doi.org/10.24916/iansa.2018.1.5

KINNAIRD, T. et al., 2017: Kinnaird, T.-Bolòs, J.-Turner, A.-Turner, S., Optically-stimulated luminescence profiling and dating of historic agricultural terraces in Catalonia (Spain), Journal of Archaeological Science 78, 66-77. https://doi.org/10.1016/j.jas.2016.11.003

KLÁPŠTĚ, J., 1978: Středověké osídlení Černokostelecka, PA LXIX, 423-475.

- 2005: Proměna českých zemí ve středověku. Praha.

- 2012: The Czech Lands in Medieval Transformation. Leiden.

KLÁPŠTĚ, J.-SMETÁNKA, Z., 1979: Geodeticko-topografický průzkum zaniklých středověkých osad, AR XXXI, 614-639.

KLÍR, T., 2003: Plužiny pozdně středověkých sídel na př́íkladě severovýchodního Nymburska, Mediaevalia Historica Bohemica 9, 245-292.

- 2008: Osídlení zemědělsky marginálních půd v mladším středověku a raném novověku. Praha.

KONOLD, W. et al., 1996: Konold, W.-Schwineköper, K.-Seiffert, P., Zukünftige Kulturlandschaft aus der Tradition heraus, Naturlandschaft-Kulturlandschaft, 289-312.

KRAHTOPOULOU, A.-FREDERICK, CH., 2008: The Stratigraphic Implications of Long-Term Terrace Agriculture in Dynamic Landscapes: Polycyclic Terracing from Kythera Island, Greece, Geoarchaeology: An International Journal 23, č. 4, 550-585. https://doi.org/10.1002/gea.20231

KRÜGER, R., 1967: Typologie des Waldhufendorfes nach Einzelformen und deren Verbreitungsmustern, (= Göttinger geographische Abhandlungen 42). Göttingen.

KUČA, K., 2014: Oblasti dochovaných strukturálně výrazných plužin v České republice, ZPP 74, 34-49. 
KUNA, M. et al., 2004: Kuna, M.-Beně̌, J.-Dreslerová, D.-Křivánek, R.-Majer, A.-Prach, K.-Tomášek, M., Nedestruktivní archeologie. Praha.

LAUGA-SAllENAVE, C., 1997: Le Cercle des Haies. Paysages des Agroéleveurs Peuls du Fouta-Djalon (Plaine des Timbis, Guinée). Thesis, Universite de Paris X.

LÁZNIČKA, Z., 1946: Typy venkovského osídlení na Moravě. Brno.

- 1956: Typy venkovského osídlení v Československu. Práce brněnské základny ČSAV 28. Brno.

LIESKOVSKÝ, J. et al., 2014: Lieskovský, J.-Kenderessy, P.-Špulerová, J.-Lieskovský, T.-Koleda, P.-Kienast, F.-Gimmi, U., Factors affecting the persistence of traditional agricultural landscapes in Slovakia during the collectivization of agriculture, Landscape Ecol 29, 867-877. https://doi.org/10.1007/s10980-014-0023-1

LÖW, J.-MÍCHAL, I., 2003: Krajinný ráz. Kostelec nad Černými Lesy.

MALINA, O., 2015: Hledání neviditelného. Relikty plužiny zaniklých středověkých vsí a možnosti jejich detekce a interpretace na datech LLS, ZPP 76, 513-520.

MAUR, E., 1996: Obyvatelstvo českých zemí ve středověku. In: Fialová, L. et al., Dějiny obyvatelstva českých zemí, 35-73. Praha.

McCOLLIN, D. et al., 2000: Mccollin, D.-Jackson, J. I.-Bunce, R. G. H.-Barr, C. J.-Stuart, R., Hedgerows as habitat for woodland plants, Journal of Environmental Management 60, 77-90. https://doi.org/10.1006/jema.2000.0363

MĚCHUROVÁ, Z., 1997: Konůvky - zaniklá středověká ves ve Ždánickém lese. Brno.

MEROT, C. et al., 1999: Merot, C.-Gascuel-Odoux, C.-Walter, C.-Zhang, X.-Molenat, J., Influence du réseau de haies des paysages bocagers sur le cheminement de l'eau de surface, Revue des sciences de l'eau 12 , č. 1, 23-44.

MĚŘÍNSKÝ, Z., 2008: Die „Villa Deserta“ als Problem der mährischen mediävistik (Archäologie und Geschichte), AH 33, 9-26.

MIMORSKI, L. A., 2019: Slovenian Terraced Landscapes. In: World Terraced Landscapes: History, Environment, Quality of Life (Varotto, M. et al., edd.), 45-62. Springer.

MOLNÁROVÁ, K., 2008a: Long-term dynamics of the structural attributes of hedgerow networks in the Czech Republic - three cases studies in areas with preserved medieval field patterns, Journal of Landscape Studies 1, 113-127.

- 2008b: Hedgerow-defined medieval field patterns in the Czech Republic and their conservation - a literature review, Journal of Landscape Studies 1, 27-47.

MOLNÁROVÁ, K. et al., 2008: Molnárová, K.-Š́mová, P.-Kotaška, J.-Ešnerová, J.-Škvárová, Š., Hedgerow-defined medieval field patterns in the Czech Republic: a case study of the dendrological and dendrochronological structure of hedgerows of varying ages in Northern Moravia, Journal of Landscape Studies 1, 145-158.

MOORHOUSE, S.-BOND, J., 2016: An approach to understanding medieval field systems across Europe: the structure and anatomy of township field systems. In: Agrarian technology in the medieval landscape. Ruralia X (Klápště, J., ed.), 1-48. Turnhout.

NEKUDA, R., 2002: Zemědělská usedlost ve středověké vesnici na Moravě. Brno.

- 1975: Pfaffenschlag - zaniklá středověká ves u Slavonic: příspěvek k dějinám středověké vesnice. Brno.

NEKUDA, V.-NEKUDA, R., 1997: Mstěnice 2: Zaniklá středověká ves u Hrotovic. Dům a dvůr ve stř̌edověké vesnici. Brno.

NĚMČENKO, N., 1970: Dějiny pozemkových úprav II. Praha.

NIELSEN, N. H. et al., 2018: Nielsen, N. H.-Holst, M. K.-Gadd, A. C.-Holst, K. K., The Layout and Internal Development of Celtic Fields: Structural and Relative Chronological Analyses of Three Danish Field Systems, European Journal of Archaeology 21(3), 385-410. https://doi.org/10.1017/eaa.2017.56

NEUSTUPNÝ, E., 1986: Sídelní areály pravěkých zemědělců - Settlement areas of prehistoric farmers, PA LXXVII, 226-234.

NUNES, J. P. et al., 2016: Nunes, J. P.-Bernard-Jannin, L.-Rodríguez Blanco, M. L.-Santos, J. M.-Alves Coehlo, C. O.-Keizer, J. J., Hydrological and erosion processes in terraced fields: Observations from a humid mediterranean region in northern Portugal, Land Degradation and Developement 29, 596-606.

PITTNEROVÁ, B., 2008: Středověké plužiny - principy jejich ochrany a obnovy v pozemkových úpravách. Disertační práce, Česká zemědělská univerzita v Praze. 
PLIENINGER, T. et al., 2016: Plieninger, T.-Draux, H.-Fagerholm, N.-Bieling, C.-Bürgi, M.-Kizos, T.Kuemmerle, T.- Primdahl, J.-Verburg, P. H., The driving forces of landscape change in Europe: A systematic review of the evidence, Land Use Policy 57, 204-214.

POHL, J., 1934-1935: Typy vesnických sídel v Čechách, Národopisný věstník Československý 27-28, $5-55$.

POLLARD, E.-HOOPER, M. D.-MOORE, N. W., 1974: Hedges. London.

POSCHLOD, P., 2015: Geschichte der Kulturlandschaft. Stuttgart.

PREGILL, P.-VOLKMAN, N., 1999: Landscapes in History. New York.

PROFOUS, A., 1947; 1949; 1951; 1957: Místní jména v Čechách. Jejich vznik, původní význam a změny. 1. díl A-H; 2. díl Ch-L; 3. díl M- ̌̌; 4. díl S-Ž. Praha.

QUIN, A.-BUREL, F., 2002: Influence of herbaceous elements on butterfly diversity in hedgerow agricultural landscapes, Agriculture, Ecosystems and Environment 93, 45-53. https://doi.org/10.1016/S0167-8809(02)00004-X

QUIRÓS-CASTILLO, J. A.-NICOSIA, C., 2019: Reconstructing past terraced agrarian landscapes in the Ebro valley: The deserted village of Torrentejo in the Basque Country, Spain, Geoarchaeology 34(6), 684-697. https://doi.org/10.1002/gea.21730

RACKHAM, O., 1986: The History of the Countryside. London.

RENES, H., 2016: Landscape history and archaeology of open fields in Europe. In: Agrarian technology in the medieval landscape, Ruralia X (Klápště, J., ed.), 255-265. Turnhout.

RIEZNER, J., 2011: Krajinný ráz území typických agrárními valy a mezemi a jejich vegetací na vybraných příkladech ze severozápadních Čech, Studia Oecologica 5, č. 2, 65-79.

ROBERTS, B. K., 1996: Landscapes of Settlement. Prehistory to the present. London - New York.

ŘÍKOVSKÝ, F., 1939: Základy k sídelnímu zeměpisu Česko-Slovenska. Brno.

SÁDLO, J., 1993: Krajina jako interpretovaný text? In: Archeologie a krajinná ekologie (Beneš, J.-Brůna, V., edd.), 47-54. Most.

SÁDLO, J. et al., 2008: Sádlo, J.-Pokorný, P.-Hájek, P.-Dreslerová, D.-Cílek, V., Krajina a revoluce. Významné přelomy ve vývoji kulturní krajiny českých zemí. Praha - Malá Skála.

SCHREG, R., 2014: Ecological Approaches in Medieval Rural Archaelogy, European Journal of Archaeology 17, č. 1, 83-119. https://doi.org/10.1179/1461957113Y.0000000045

SEEGER, M.-RIES, J. B., 2008: Soil degradation and soil surface process intensities on abandoned fileds in mediterranean mountain environmets, Land degradation and Developement 19, 488-501. https://doi.org/10.1002/ldr.854

SKLENIČKA, P. et al., 2009: Sklenička, P.-Molnárová, K.-Brabec, E.-Kumble, P.-Pittnerová, B.-Pixová, K.-Š́lek, M., Remnants of medieval field patterns in the Czech Republic: Analysis of driving forces behind their disappearance with special attention to the role of hedgerows, Agriculture, Ecosystems and Environment 129, 465-473. https://doi.org/10.1016/j.agee.2008.10.026

SKLENIČKA, P. et al., 2017: Sklenička, P.-Kottová, B.-Šálek, M., Success in preserving historic rural landscapes under various policy measures: Incentives, restrictions or planning?, Environmental Science and Policy 75, 1-9. https://doi.org/10.1016/j.envsci.2017.05.010

SMETÁNKA, Z., 1988: Život středověké vesnice: Zaniklá Svídna. Praha.

- 1992: Legenda o Ostojovi. Praha.

SMETÁNKA, Z.-KLÁPŠTĚ, J., 1981: Geodeticko-topografický průzkum zaniklých středověkých vsí v Československu, PA LXXII, 416-458.

SPERLING, W., 1982: Formen, Typen und Genese des Platzdorfes in den böhmischen Ländern: Beiträge zur Siedlungsgeographie Ostmitteleuropas. Wiesbaden.

STANCHI, S. et al., 2012: Stanchi, S.-Freppaz, M.-Agnelli, A.-Reinsch, T.-Zanini, E., Properties, best management practices and conservation of terraced soils in Southern Europe (from Mediterranean areas to the Alps): A review, Quaternary International 265, 90-100. https://doi.org/10.1016/j.quaint.2011.09.015

ŠITNEROVÁ, I. et al., 2020: Šitnerová, I.-Beneš, J.-Trpáková, I.-Bumerl, J.-Komárková, V.-Majerovičová, T.-Hrabáková, L.-Janečková, K., Landscape Transformed: Archaeological, Historical and Environmental Dating of the Early Modern Field System in Valštejn, Czech Republic, Interdisciplinaria Archaeologica, 11.1, submitován. 
ŠTEFUNKOVÁ, D.-HANUŠIN, J., 2019: Viticultural landscapes: Localised transformations over the past 150 years through an analysis of three case studies in Slovakia, Moravian Geographical Reports 27(3), 155-168. https://doi.org/10.2478/mgr-2019-0012

SUTTON, R. K., 1985: Relict rural planting in Eastern Nebraska, Landscape Journal 4, 106115. https://doi.org/10.3368/1j.4.2.106

ŠTĚPÁNEK, M., 1967: Plužina jako pramen dějin osídlení (Příspěvky k dějinám osídlení 1), ČČH 15, 725-746. - 1968: Plužina jako pramen dějin osídlení (Příspěvky k dějinám osídlení 2), ČČH 16, $247-274$.

TAROLLI, P. et al., 2014: Tarolli, P.-Preti, F.-Romano, N., Terraced landscapes: From an old best practice to a potential hazard for soil degradation due to land abandonment, Anthropocene 6, 1025. https://doi.org/10.1016/j.ancene.2014.03.002

TAROLLI, P.-RIZZO, D.-BRANCUCCI, G., 2019: Terraced Landscapes: Land Abandonment, Soil Degradation, and Suitable Management. In: World Terraced Landscapes: History, Environment, Quality of Life (Varotto, M. et al., edd.), 195-211. Springer.

UHLIG, H.-LIENAU, C., edd., 1978: Flur und Flurformen - Types of Field Patterns - Le Finage agricole et sa structure parcellaire (= Materialen zur Terminologie der Agrarlandschaft, Vol. I). Giessen.

VAROTTO, M.-BONARDI, L.-TAROLLI, P., edd., 2019: World Terraced Landscapes: History, Environment, Quality of Life, Environmental History 9.

VERHULST, A., 1995: Le paysage rural: Les structures parcellaires de l'Europe du Nord-Ouest (Typologie des sources du Moyen Age occidental). Brepols.

VERMOUZEK, R., 1982: Plužina jako datovací pomůcka - Die Flurtrassen als Datationshilfsmittel, AH 7 , 265-276.

VOTRUBEC, C., 1980: Lidská sídla, jejich typy a rozmístění ve světě. Praha.

ZÍMOVÁ, K. et al., 2013: Zímová, K.-Pospíšil, L.-Janovská, V.-Karlík, P.-Houfková, P.-Bumerl, J.-Molnárová, K.-Beneš, J.-Bernardová, A., Analýza vývoje plužiny zaniklé obce Malonín na Prachaticku, Acta Pruhoniciana 104, 27-37.

WEI, W. et al., 2016: Wei, W.-Chena, D.-Wang, C. L.-Daryanto, S.-Chen, L.-Yua, Y.-Lu, Y.-Sun, G.Feng, T., Global synthesis of the classifications, distributions, benefits and issues of terracing, Earth-Science Reviews 159, 388-403. https://oi.org/10.1016/j.earscirev.2016.06.010

WIEZIK, M. et al., 2017: Wiezik, M.-Gallay, I.-Wieziková, A.-Čiliak, M.-Dovciak, M., Spatial structure of traditional land organization allows long-term persistence of large Formica exsecta supercolony in actively managed agricultural landscape, J. Insect Conserv. 21(2), 257-266. https://doi.org/10.1007/s10841-017-9973-3

ŽEMLIČKA, J., 1974: Osídlení Zbraslavska od 10. do počátku 15. století, PA LXV, 419-465.

- 1980: Vývoj osídlení dolního Poohří a Českého středohoří do 14. století. Praha.

- 1997: Čechy v době knížecí (1034-1198). Praha.

- 2014: Království v pohybu. Kolonizace, města a stř́bro v závěru Přemyslovské epochy. Praha.

\section{Zusammenfassung}

Die archäologische Erforschung von Fluren und landwirtschaftlichen Terrassen als Phänomen der historischen Landschaft der Tschechischen Republik

$\mathrm{Zu}$ den ältesten Feldsystemtypen gehören Terrassenfelder und durch Grenzstreifen abgegrenzte Felder. Sie sind bereits ab dem Neolithikum ein Phänomen und existieren quer durch die ganze Welt in Regionen mit einer Höhengliederung des Geländes. Terrassenfelder wurden zu dem Zweck angelegt, den Boden in höheren Lagen und an Steilhängen zu bewirtschaften. Die Grundeigenschaft dieser Felder bestand darin, mehr Wasser aufzunehmen, die Bewässerung zu optimieren und die Bodenerosion einzudämmen. In Europa wurden Terrassenfelder zum Anbau von Wein und Oliven angelegt (z.B. im Gebiet Cinque Terre in Italien), während man in Asien, Afrika und Amerika Terrassen in Abhängigkeit vom jeweiligen Gebiet zum Anbau von Halmfrüchten wie beispielsweise Mais, Reis, Sorghum und Hirse nutzte. Ein weiteres Phänomen sind von Grenzstreifen begrenzte Felder. 
Die Funktion der Grenzstreifen beruhte nicht nur in der Abgrenzung der Grundstücke, sondern sie beeinflussten auch physische, chemische und biologische Prozesse (Entwässerung, Bewässerung, Erosionsminderung). Sie dienten auch als Windschutz und gewährleisteten ebenfalls die Bereitstellung von Rohstoffen, vor allem von Brennholz und weiterer Grundstoffe wie Obst (z.B. Waldfrüchte), Heilkräuter (z.B. Brennesseln) oder Materialien für die Gerätschaften (z.B. Weidenruten). In der heutigen Zeit, in der die meisten Grenzstreifen nicht mehr ihren ursprünglichen Zweck erfüllen, werden sie wegen ihres historischen, visuellen und vor allem ökologischen Wertes geschätzt.

Allgemein werden Fluren als bewirtschaftbarer Teil der Landschaft charakterisiert, der einer Dorfsiedlung angehört; dabei handelt es sich um die Summe aller Felder, Wiesen und Weiden, die durch ein Wegenetz miteinander verbunden sind. Fluren können in eine Reihe von Typen untergliedert werden, je nachdem wie der Grundbesitz der einzelnen Anwesen im Rahmen des Dorfes darin verteilt ist und über welches Gelände es sich erstreckt.

Für lange Zeit waren Fluren in der Tschechischen Republik aus archäologischer Sicht ein übergangenes Phänomen. Das Interesse der Archäologen heftete sich bei der Erforschung wüster Siedlungen hauptsächlich auf das Intravillan der Dörfer. In den achtziger und neunziger Jahren begann sich das Interesse der Archäologen dank des Aufschwungs der Luftbildarchäologie auf die Landschaft als Forschungssubjekt zu verlagern, die man als Ganzheit zu untersuchen begann. Es entstand ein neuer Fachzweig - die Landschaftsarchäologie, zu deren Wiege Großbritannien wurde. Auf diese Weisen begannen in größerem Maße geoarchäologische und bioarchäologische Methoden in die Archäologie vorzudringen. In den letzten Jahrzehnten begannen sich auch die Forscher im Fach der Landschaftsökologie auf die traditionellen Feldsysteme und ihre ökologische Bedeutung zu konzentrieren, die den hohen Environmental-Wert dieses Teils der Landschaft hervorheben.

Eine der ersten archäologischen Untersuchungen in Tschechien, bei der es zu einer Identifizierung von Fluren kam, wurde von Zdeněk Smetánka und Jan Klápště an mittelalterlichen Dorfwüstungen im Gebiet von Schwartzkosteletz (Kostelec nad Černými lesy) durchgeführt. Die erste selbständige direkte archäologische Untersuchung von Agrarrelikten in Tschechien erfolgte im Böhmerwald in der Gegend von Vlachovo Březí im Kataster der Gemeinde Dolní Kožlí. Die erste detaillierte Multiproxy-Analyse eines Feldsystems in der Tschechischen Republik wurde für die Dorfwüstung Malonín in der Region Prachatice durchgeführt.

Gegenwärtig wird ein Förderprojekt des Programms zur Förderung von angewandter Forschung und experimenteller Entwicklung der nationalen und kulturellen Identität durchgeführt, das sich zum Ziel gesetzt hat, Informationen zu liefern und Methoden und Instrumente zu entwickeln, die auf den Schutz von historischen Fluren ausgerichtet sind, die auf dem Territorium der Tschechischen Republik zu den wertvollsten, aber auch zu den übergangensten historischen Kulturlandschaften gehören. Die Ergebnisse liefern die Grundlage für einen qualifizierten Schutz historischer Feldsysteme, der in Tschechien, aber auch im weltweiten Maßstab gerade wegen des multidisziplinären Charakters der Problematik bisher nicht vorhanden ist.

Der vorliegende Artikel entstand im Rahmen des Förderprogramms Identifizierung und Schutz historischen Fluren - Identification and preservation of historic field patterns NAKI II - DG18P02OVV060.

Mgr. Ivana Šitnerová, Laboratoř archeobotaniky a paleoekologie Př́rodovědecké fakulty Jihočeské univerzity, Na Zlaté stoce 3, 37005 České Budějovice; Archeologický ústav Filozofické fakulty Jihočeské univerzity, Branišovská 31a, 37005 České Budějovice, Česká republika, ivana.pravcova@gmail.com

doc. PhDr. Jaromír Beneš, Ph.D., Laboratoř archeobotaniky a paleoekologie Přírodovědecké fakulty Jihočeské univerzity, Na Zlaté stoce 3, 37005 České Budějovice; Archeologický ústav Filozofické fakulty Jihočeské univerzity, Branišovská 31a, 37005 České Budějovice, Česká republika, benes.jaromir@gmail.com 
Ing. Blanka Kottová, Ph.D., Katedra biotechnických úprav krajiny Fakulty životního prostředí České zemědělské univerzity, Kamýcká 129, 16521 Praha 6-Suchdol, Česká republika, kottovab@fzp.czu.cz

Mgr. Jiří Bumerl, Laboratoř archeobotaniky a paleoekologie Př́rodovědecké fakulty Jihočeské univerzity, Na Zlaté stoce 3, 37005 České Budějovice; Archeologický ústav Filozofické fakulty Jihočeské univerzity, Branišovská 31a, 37005 České Budějovice, Česká republika,jbumca@gmail.com

Mgr. Tereza Majerovičová, Laboratoř archeobotaniky a paleoekologie Přírodovědecké fakulty Jihočeské univerzity, Na Zlaté stoce 3, 37005 České Budějovice; Archeologický ústav Filozofické fakulty Jihočeské univerzity, Branišovská 31a, 37005 České Budějovice, Česká republika, tmajerovicova@gmail.com

doc. Ing. Kristina Janečková, Ph.D., Katedra biotechnických úprav krajiny Fakulty životního prostředí České zemědělské univerzity, Kamýcká 129, 16521 Praha 6-Suchdol, Česká republika, kristina.janeckova19@gmail.com 
